\title{
A comparative study of test methods for assessment of fire safety performance of bus interior materials
}

Michael Försth 


\section{A comparative study of test methods for assessment of fire safety performance of bus interior materials}

Michael Försth 


\section{Abstract}

\section{A comparative study of test methods for assessment of fire safety performance of bus interior materials}

This work concerns the assessment of fire performance of interior materials used in buses. The widely used test method ISO 3795/FMVSS 302 has received much criticism mainly based on the fact that the test specimens are oriented horizontally while much fire spread in a real bus fire occurs on vertically oriented products. Eleven (11) different materials have been investigated, nine textiles and two solid materials. Three different test methods were used: ISO 3795, ISO 6941, and ISO 5658-2. Given the existing criteria for interior materials it was found that both ISO 6941 and ISO 5658-2 place much harder requirements on the materials. While only one material failed the ISO 3795 test as many as seven and six materials failed the ISO 6941 and ISO 5658-2 tests, respectively.

Further, it was found that correlation between the different methods was poor.

Key words: bus, fire, interior materials, ISO 5658, ECE 118, EU directive 95/28/CE

SP Sveriges Tekniska Forskningsinstitut

SP Technical Research Institute of Sweden

SP Arbetsrapport 2009:23

ISSN 0284-5172

Borås 2009 


\section{Contents}

$1 \quad$ Introduction 7

2 Materials and Methods $\quad 7$

2.1 Tested products $\quad 7$

2.2 Test of horizontal burning rate (ISO 3795, ECE Reg No 118 annex 6, directive 95/28/CE annex IV) 7

Test of vertical burning rate (ISO 6941, ECE Reg No 118 annex 8,
directive 95/28/CE annex VI)

2.4 Test of Spread of Flame, SoF (ISO 5658-2) 9

$3 \quad$ Results $\quad 11$

3.1 Horizontal burning rate (ISO 3795, ECE Reg No 118 annex 6,
directive 95/28/CE annex IV)

Vertical burning rate (ISO 6941, ECE Reg No 118 annex 8,
directive 95/28/CE annex VI)

$\begin{array}{lll}3.3 & \text { Spread of Flame, SoF (ISO 5658-2) } & 13\end{array}$

$4 \quad$ Assessment of results and conclusions $\quad 14$

Appendix A Results horizontal burning rate (ISO 3795, ECE Reg No 118 annex 6, directive 95/28/CE annex IV)

$\begin{array}{lll}\text { A.1 Product No. } 1 & 15\end{array}$

$\begin{array}{lll}\text { A.2 Product No. } 2 & 16\end{array}$

$\begin{array}{lll}\text { A.3 Product No. } 3 & 17\end{array}$

$\begin{array}{lll}\text { A.4 Product No. } 4 & 18\end{array}$

$\begin{array}{lll}\text { A.5 Product No. } 5 & 19\end{array}$

$\begin{array}{ll}\text { A.6 Product No. } 6 & 20\end{array}$

$\begin{array}{lll}\text { A.7 Product No. } 7 & 21\end{array}$

$\begin{array}{lll}\text { A.8 } & \text { Product No. } 8 & 22\end{array}$

A.9 Product No. $9 \quad 23$

$\begin{array}{lll}\text { A.10 Product No. } 10 & 24\end{array}$

$\begin{array}{lll}\text { A.11 Product No. } 11 & 25\end{array}$

Appendix B Results vertical burning rate (ISO 6941, ECE Reg No 118 annex 8, directive 95/28/CE annex VI) 26

B.1 Product No. $1 \quad 26$

$\begin{array}{ll}\text { B.2 Product No. } 2 & 27\end{array}$

$\begin{array}{ll}\text { B.3 Product No. } 3 & 28\end{array}$

B.4 Product No. $4 \quad 29$

$\begin{array}{lll}\text { B.5 Product No. } 5 & 30\end{array}$

B.6 Product No. $6 \quad 31$

B.7 Product No. $7 \quad 32$

B.8 Product No. $8 \quad 33$

\begin{tabular}{lll} 
B.9 Product No. 9 & 34 \\
\hline
\end{tabular}

B.10 Product No. $10 \quad 35$

$\begin{array}{lll}\text { B.11 Product No. } 11 & 36\end{array}$

Appendix C Results Spread of Flame, SoF (ISO 5658-2) 37

$\begin{array}{lll}\text { C.1 } & \text { Product No. } 1 & 37\end{array}$

$\begin{array}{lll}\text { C. } 2 \text { Product No. } 2 & 40\end{array}$ 
C. 3 Product No. 3

43

C. 4 Product No. 4

46

C.5 Product No. 5

49

C.6 Product No. 6

52

C.7 Product No. 7

55

C.8 Product No. 8

58

C.9 Product No. 9

61

C.10 Product No. 10

62

C.11 Product No. 11

64

References 


\section{Preface}

The Swedish Transport Agency and Norwegian Public Roads Administration are gratefully acknowledged for their financial support. Special thanks are given to Brith

Månsson, Hans Boström and Sven-Ove Vendel for conducting all tests reported here. 


\section{Introduction}

The test method ISO 3795 [1] is prescribed for approval of interior material in buses according to references $[2,3]$. According to this method specimens are tested in horizontal orientation and the burning rate is measured and used as the parameter to assess compliance. The method, or the similar method FMVSS 302 [4], has received severe criticism, especially during recent years [5-7]. The main part of the criticism concerns the horizontal orientation of the test sample. Fire performance is expected to be worse for products oriented vertically, such as seat backs or wall linings. As a results alternative or complementary test methods have been proposed. These are ISO 6941 [8, 9] and ISO 5658-2 [10, 11]. ISO 6941 is a method originally conceived for relatively thin textile fabrics such as curtains. ISO 5658-2 is a method for assessing the fire performance of vertically oriented materials, and it is already used by the ship [12] and train [13] industries.

In this study we have compared the three test methods (ISO 3795, ISO 6941 and ISO 5658-2) for 11 materials commonly used in bus passenger areas.

\section{Materials and Methods}

\subsection{Tested products}

All 11 products are typically used as interior material in buses. A summary of the products is given in Table 1.

Table 1 Summary of the tested products.

\begin{tabular}{|l|l|l|l|l|}
\hline $\begin{array}{l}\text { Prod. } \\
\text { No. }\end{array}$ & Description & Content & $\begin{array}{l}\text { Thickness } \\
{[\mathrm{mm}]}\end{array}$ & $\begin{array}{l}\text { Weight } \\
\text { per area } \\
{\left[\mathrm{g} / \mathrm{m}^{2}\right]}\end{array}$ \\
\hline 1 & Plastic & ABS & 3.1 & 3040 \\
\hline 2 & Perstorp laminate & Paper-reinforced thermosetting plastic & 5.8 & 8780 \\
\hline 3 & Fabric & Wool velvet blend & 2.8 & 311 \\
\hline 4 & Artificial leather & $91.5 \%$ PVC + 0.5\% Polyamide & 1.1 & 814 \\
\hline 5 & Fabric & $70 \%$ PES + 30\% wool & 3.2 & 627 \\
\hline 6 & Fabric & $55 \%$ Polyester + 45\% wool & 3.9 & 829 \\
\hline 7 & Fabric & Wool velvet blend & 4.4 & 973 \\
\hline 8 & Fabric & $85 \%$ wool + 15\% nylon & 4.3 & 856 \\
\hline 9 & Fabric & $65 \%$ PES + 20\% wool + $15 \%$ CV & 3.0 & 676 \\
\hline 10 & Fabric & $56 \%$ wool + 35\% cotton $+9 \%$ nylon & 4.2 & 826 \\
\hline 11 & Fabric & Polypropylene fibre & 4.4 & 510 \\
\hline
\end{tabular}

\subsection{Test of horizontal burning rate (ISO 3795, ECE Reg No 118 annex 6, directive 95/28/CE annex IV)}

At present products for use in the interior of buses are mainly regulated by the international standard ISO 3795 . The principle of ISO 3795 is that a $100 \mathrm{~mm} \times 356 \mathrm{~mm}$ sample is mounted horizontally in a U-shaped holder and is exposed to the action of a well-defined low-energy flame for 15 seconds in a combustion chamber. The flame is 
applied to the free end of the sample, see Figure 1. The test determines if and when the flame extinguishes, or the time at which the flame passes a measured distance, resulting in a burning rate in $\mathrm{mm} /$ minute [6].

A similar test method is FMVSS (Federal Motor Vehicle Safety Standard) 302. The differences are very small and test results from one of the tests can be directly compared to the other. This test or variations are widely used all over the world for passenger car fire safety testing.

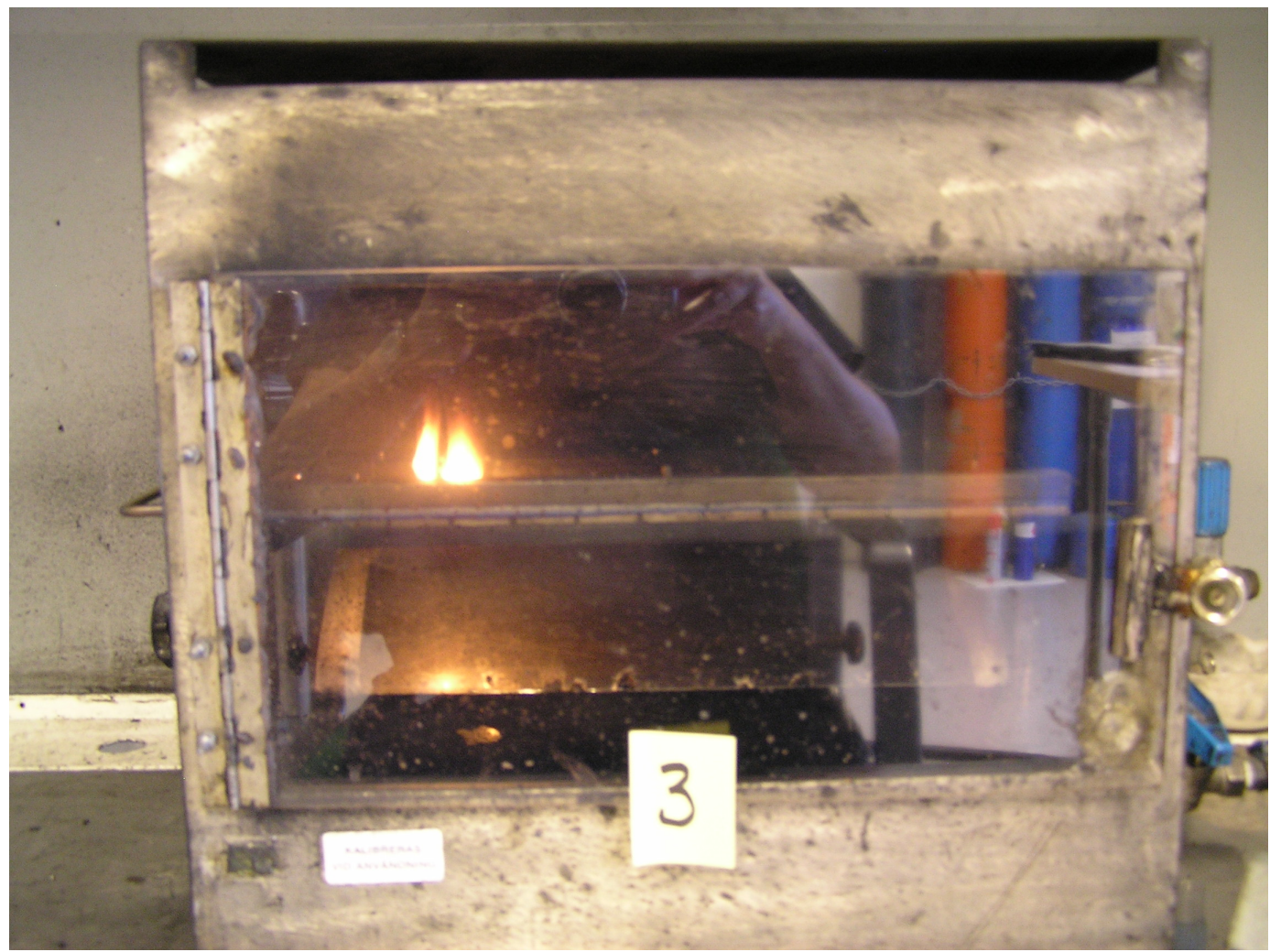

Figure 1 Test of Product No. 3 according to ISO 3795.

\subsection{Test of vertical burning rate (ISO 6941, ECE Reg No 118 annex 8, directive 95/28/CE annex VI)}

Curtain, blinds and other vertical hanging materials in buses are presently regulated by the European directive 95/28/EC; annex VI, which describes a test method which is identical to the international standard ISO 6941.

The principle of ISO 6941 is that a sample is held vertically, fastened by pins located on a steel frame. The sample is exposed from below with a $40 \mathrm{~mm}$ long flame for 5 or 15 seconds. At three different heights a marker thread is placed horizontally across the sample surface. The time for the flame to burn off each marker thread is measured. The vertical burning rate to each marker thread is calculated and the fastest burning rate is taken into account for classification [6], see Figure 2. 


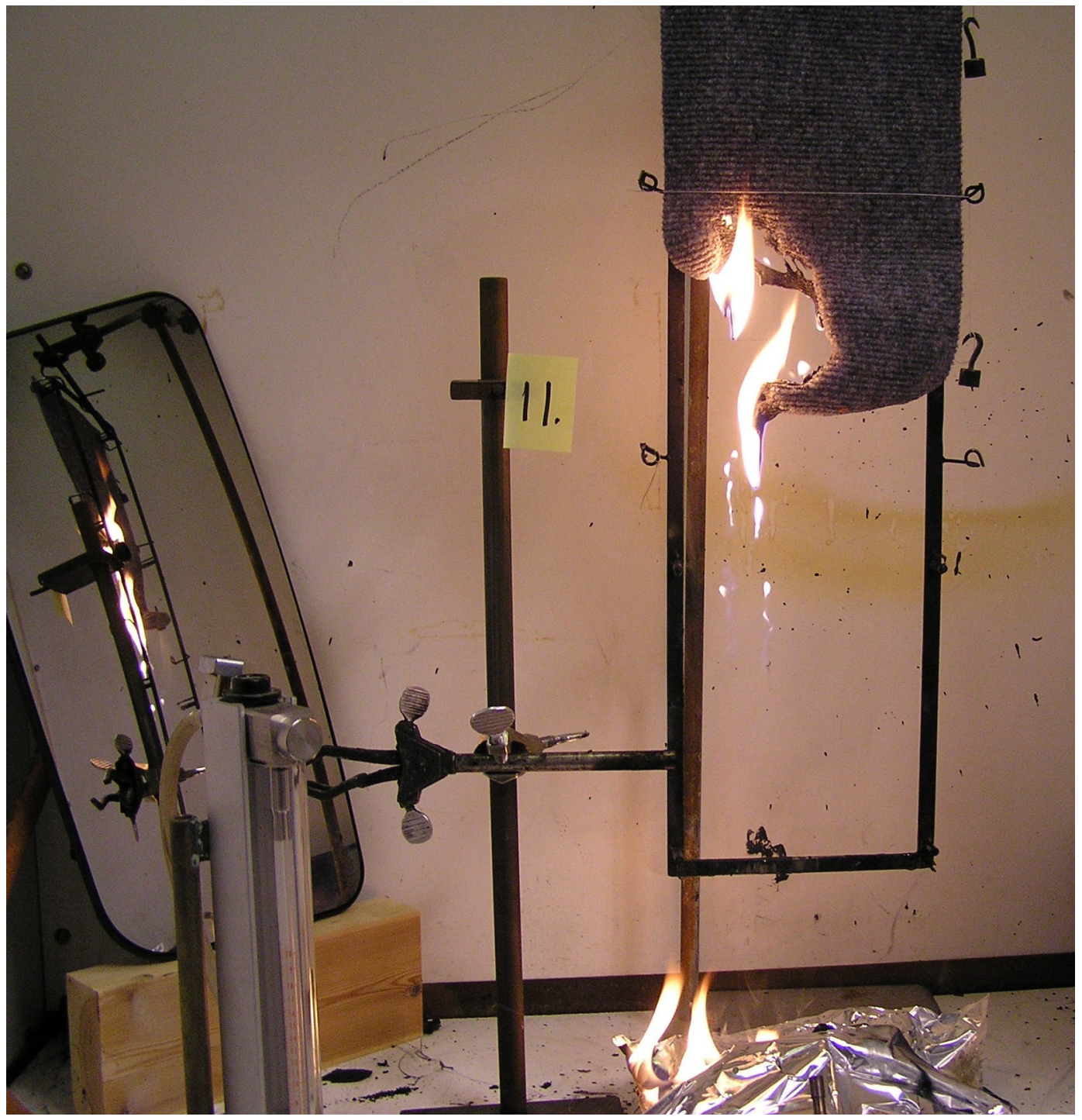

Figure 2 Test of Product No. 11 according to ISO 6941.

\subsection{Test of Spread of Flame, SoF (ISO 5658-2)}

To determine a product's behaviour regarding lateral flame spread the international standard ISO 5658-2 is used in the proposed European system for fire safety on trains CEN/TS 45545-2 [13]. The same test procedure but with some additional measurements is used as the main flame spread test for interior linings in passenger ships under the IMO Resolution A.653(16) [12].

The lateral flame spread is determined on vertically orientated specimens exposed to radiant heat from a methane-fuelled rectangular radiant panel at an angle to the specimen as shown in Figure 3. A small gas burner flame impinging on the sample acts as the pilot ignition source [6].

The distance of the flame spread is used for reporting the CFE-value for both trains and ships. The CFE-value (Critical heat Flux at Extinguishment) is the incident heat flux at the specimen surface at the point along its horizontal centreline where the flame ceases to advance. The CFE-value, $\mathrm{kW} / \mathrm{m}^{2}$, is determined by measuring the maximum spread of flame and relating this value to the corresponding heat flux value from the heat flux profile curve, the calibration curve, which is based on measurements conducted using a non-combustible board. 
The specimen were attached to a non-combustible backing-board using staples along the upper edge. During the test, the staples were hidden under the specimen holder.

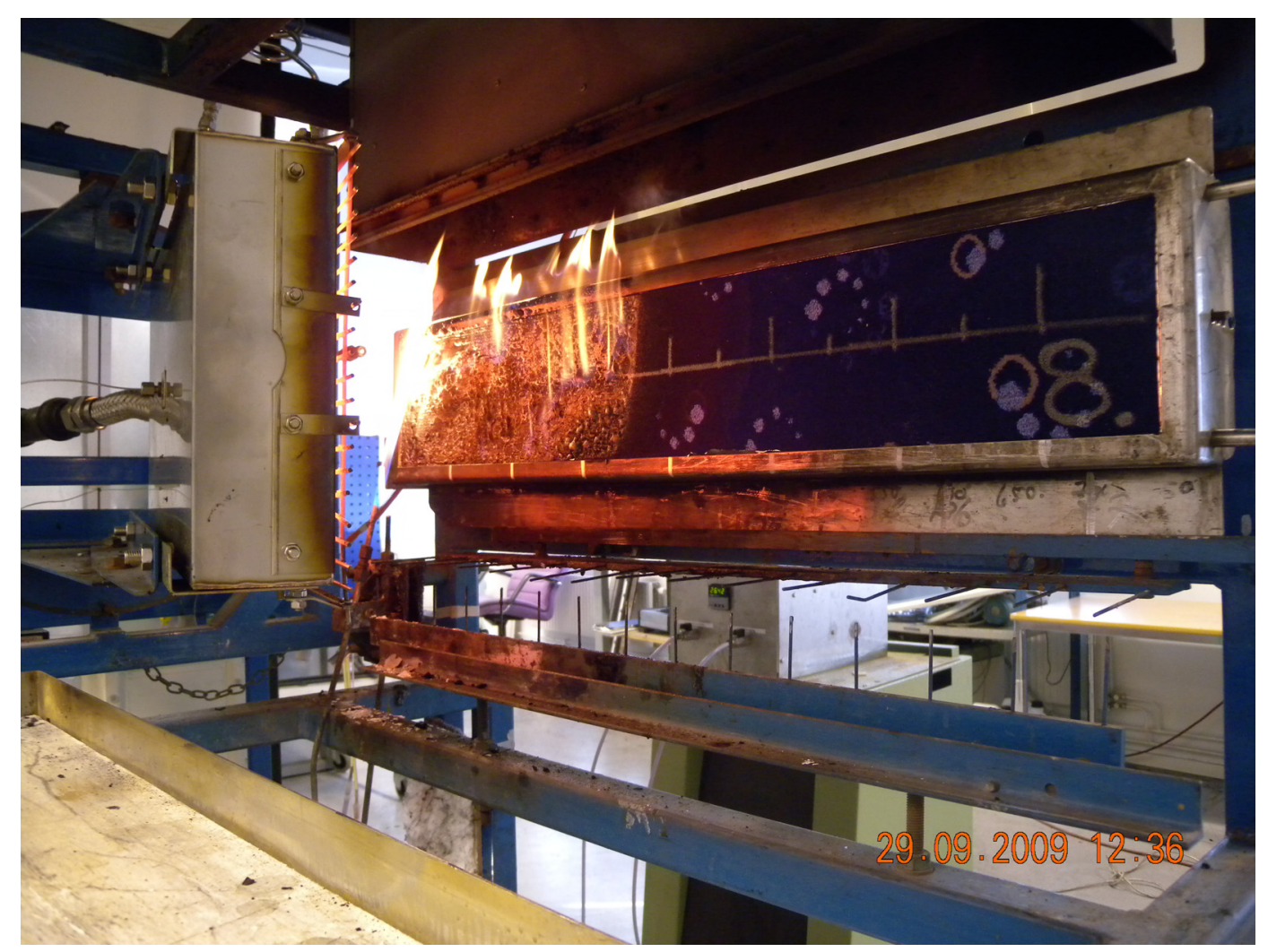

Figure 3 Test of Product No. 8 according to ISO 5658-2. 


\section{Results}

\subsection{Horizontal burning rate (ISO 3795, ECE Reg No 118 annex 6, directive 95/28/CE annex IV)}

The results from the tests of horizontal burning rate are given in Figure 4. A detailed account of all test results are given in Appendix A.

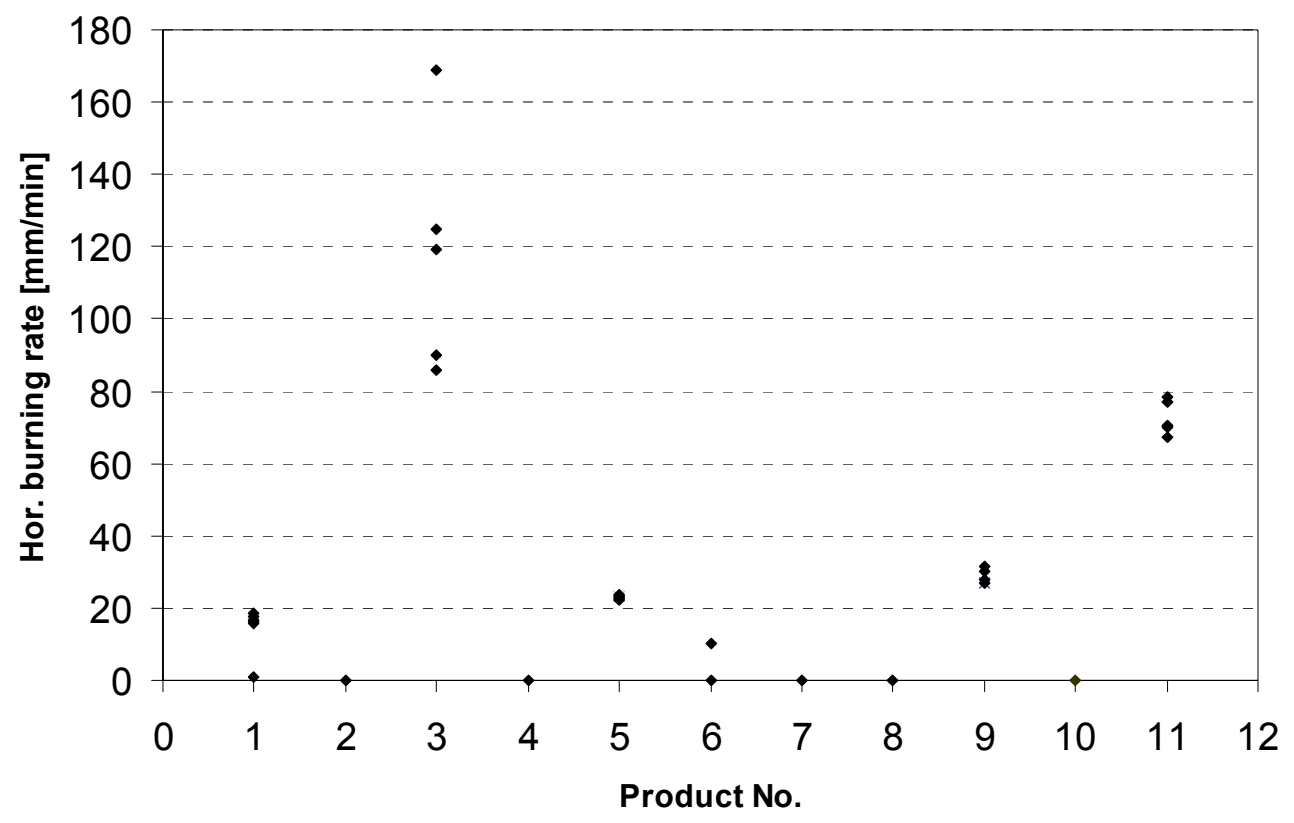

Figure 4 Results for horizontal burning rate according to ISO 3795 . 


\subsection{Vertical burning rate (ISO 6941, ECE Reg No 118 annex 8, directive 95/28/CE annex VI)}

The results from the tests of vertical burning rate are given in Figure 5. A detailed account of all test results are given in Appendix B.

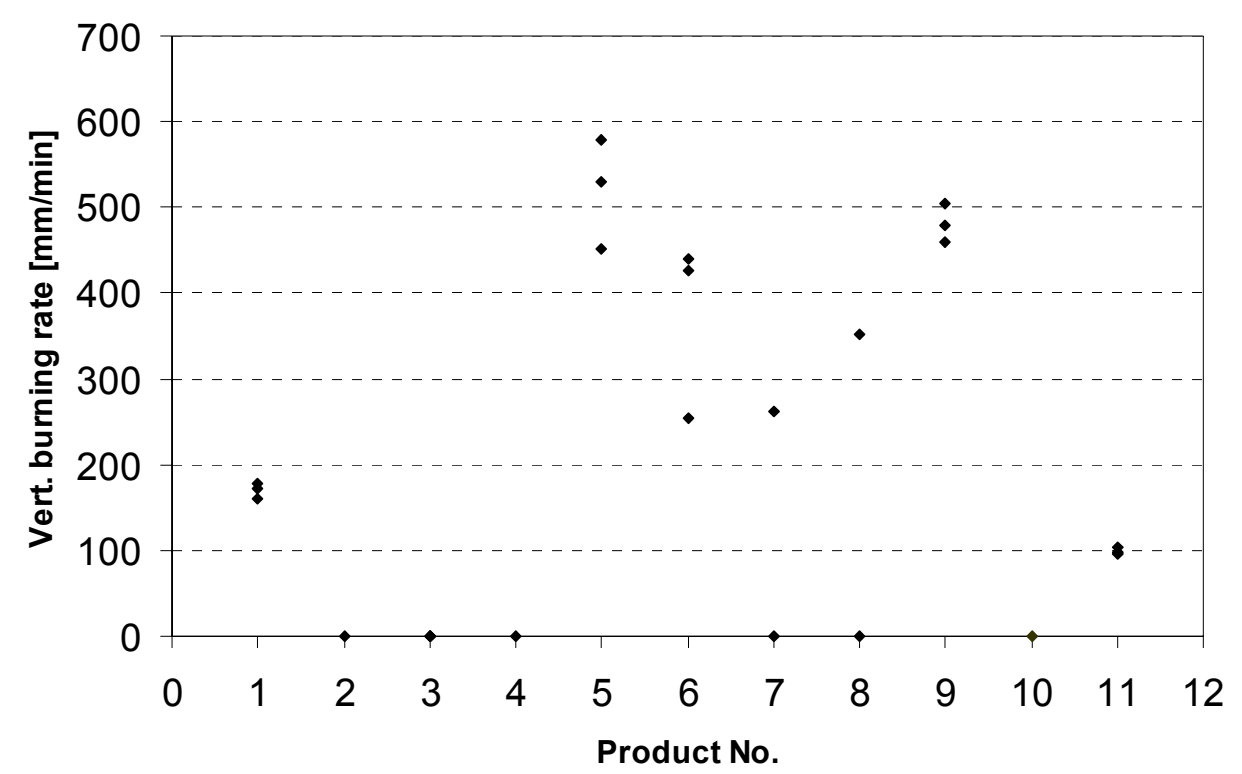

Figure 5 Results for vertical burning rate according to ISO 6941. 


\subsection{Spread of Flame, SoF (ISO 5658-2)}

The results from the tests of CFE (Critical heat Flux at Extinguishment) are given in Figure 6. A detailed account of all test results are given in Appendix C.

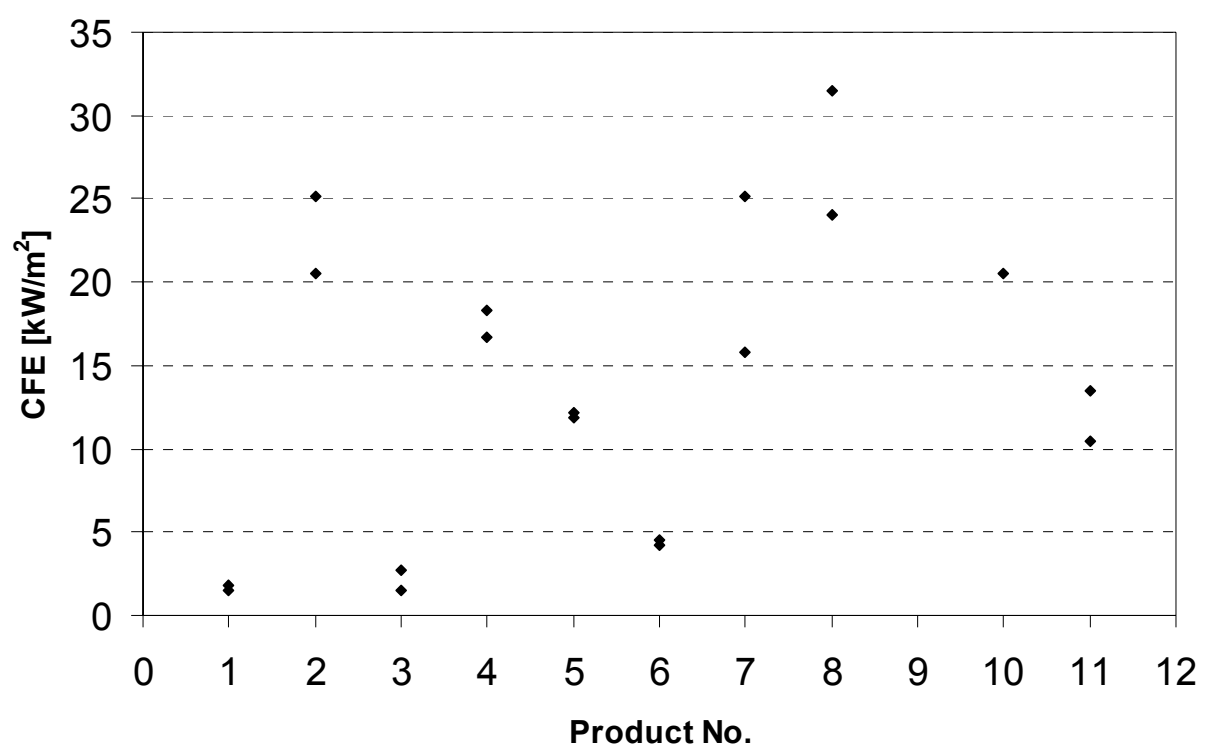

Figure 6 Results for CFE (Critical heat Flux at Extinguishment) according to ISO 5658-2 (Spread of Flame). 


\section{Assessment of results and conclusions}

According to ECE Reg No. 118 [3] and directive 95/28/CE [2] the result of the tests shall be considered satisfactory if, taking the worst results into account, the horizontal or vertical burning rate is not more than $100 \mathrm{~mm} /$ minute.

According to IMO Res A.653(16) [12] and CEN/TS 45545-2 [13], Requirement 1, the average critical heat flux at extinguishment, CFE, should be $20 \mathrm{~kW} / \mathrm{m}^{2}$ when evaluated according to the test standard ISO 5658-2, Spread of Flame (SoF), for a material to be considered satisfactory ${ }^{1}$. As a consequence $20 \mathrm{~kW} / \mathrm{m}^{2}$ has been suggested as an amendment to ECE Reg No. 118 [14].

Table 2 summarizes all test results. It is clear that ISO 3795, horizontal burning rate, is the most lenient test method given the criteria for approval above. Approximately $91 \%$ $(10 / 11)$ of the products passed the requirement for ISO 3795. If the products are tested for their vertical burning rate according to ISO 6941 instead the situation is very different. Only $36 \%(4 / 11)$ of the products pass the requirements for ISO 6941 . This could be expected since vertical flame spread is more effective due to more effective heat transfer from the flames to the specimen. Furthermore, ISO 6941 and the criterion $100 \mathrm{~mm} / \mathrm{min}$ were originally conceived for curtains which typically are treated with a flame retardant. Finally $40 \%$ (4/10) of the products pass the requirements for spread of flame according to ISO 5658.

In general there is little or no correlation between the test methods and the associated test criteria. It is only for product No. 2 (Perstorp laminate) and No. 10 (fabric) that all methods give the same, positive, result.

Table 2 Summary of test results. For horizontal and vertical burning rate the worst result is presented. For spread of flame the average test result is presented.

\begin{tabular}{|l|l|l|l|l|l|l|l|}
\hline $\begin{array}{l}\text { Prod } \\
\text { No. }\end{array}$ & $\begin{array}{l}\text { Thickness } \\
{[\mathrm{mm}] / \text { Area }} \\
\text { weight } \\
{\left[\mathrm{g} / \mathrm{m}^{2}\right]}\end{array}$ & $\begin{array}{l}\text { Hor. } \\
\text { burning } \\
\text { rate } \\
{[\mathrm{mm} / \mathrm{min}]}\end{array}$ & $\begin{array}{l}\text { Hor. } \\
\text { pass/fail }\end{array}$ & $\begin{array}{l}\text { Vert. } \\
\text { burning } \\
\text { rate } \\
{[\mathrm{mm} / \mathrm{min}]}\end{array}$ & $\begin{array}{l}\text { Vert. } \\
\text { pass/fail }\end{array}$ & $\begin{array}{l}\text { SoF } \\
{[\mathrm{kW} / \mathrm{m} 2]}\end{array}$ & $\begin{array}{l}\text { SoF } \\
\text { pass/fail }\end{array}$ \\
\hline 1 & $3.1 / 3040$ & 19 & pass & 178 & fail & 1.64 & fail \\
\hline 2 & $5.8 / 8780$ & 0 & pass & 0 & pass & 22.8 & pass \\
\hline 3 & $2.8 / 311$ & 169 & fail & 0 & pass & 2.12 & fail \\
\hline 4 & $1.1 / 814$ & 0 & pass & 0 & pass & 17.5 & fail \\
\hline 5 & $3.2 / 627$ & 24 & pass & 578 & fail & 12.0 & fail \\
\hline 6 & $3.9 / 829$ & 10 & pass & 440 & fail & 4.35 & fail \\
\hline 7 & $4.4 / 973$ & 0 & pass & 262 & fail & 20.4 & pass \\
\hline 8 & $4.3 / 856$ & 0 & pass & 351 & fail & 27.8 & pass \\
\hline 9 & $3.0 / 676$ & 31 & pass & 505 & fail & $-*$ & -* \\
\hline 10 & $4.2 / 826$ & 0 & pass & 0 & pass & 20.5 & pass \\
\hline 11 & $4.4 / 510$ & 79 & pass & 103 & fail & 12.0 & fail \\
\hline
\end{tabular}

* No tests performed due to lack of material.

\footnotetext{
${ }^{1}$ This criterion is not required for floor coverings.
} 


\section{Appendix A Results horizontal burning rate (ISO 3795, ECE Reg No 118 annex 6, directive 95/28/CE annex IV)}

\section{A.1 Product No. 1}

Light grey ABS plastics. The product has an area weight of $3040 \mathrm{~g} / \mathrm{m}^{2}$.

\section{A.1.1 Observations made during fire test}

Test no

Sample dimension, $\mathrm{mm}$

$$
\text { length }
$$

width

thickness

Burnt distance, $\mathrm{mm}$

Burning time, s

Burning rate, $\mathrm{mm} / \mathrm{min}$

\section{1}

2

3

4

5

\section{A.1.2 Conditioning}

Temperature $23 \pm 2{ }^{\circ} \mathrm{C}$.

Relative humidity $(50 \pm 5) \%$.

\section{A.1.3 Test conditions}

The combustion chamber was placed in a fume cupboard according to standard.

\section{A.1.4 Date of test}

September 2 and 8, 2009. 


\section{A.2 Product No. 2}

Dark grey Perstorp Compactlaminate consisting of paper-reinforced thermosetting plastic (two-side high pressure laminate). The product is used in partitions. The product has an area weight of $8780 \mathrm{~g} / \mathrm{m}^{2}$.

\section{A.2.1 Observations made during fire test}

Test no

1

2

3

4

5

Sample dimension, $\mathrm{mm}$

$\begin{array}{llllll}\text { length } & 320 & 320 & 320 & 320 & 320 \\ \text { width } & 70 & 70 & 70 & 70 & 70 \\ \text { thickness } & 5.8 & 5.8 & 5.8 & 5.8 & 5.8\end{array}$

Burnt distance, $\mathrm{mm}$

Burning time, $s$

Burning rate, $\mathrm{mm} / \mathrm{min}$

* In tests no 1 - 5 the flames died out before reaching the first measuring point.

\section{A.2.2 Conditioning}

Temperature $23 \pm 2{ }^{\circ} \mathrm{C}$.

Relative humidity $(50 \pm 5) \%$.

\section{A.2.3 Test conditions}

The combustion chamber was placed in a fume cupboard according to standard.

\section{A.2.4 Date of test}

August 31, 2009. 


\section{A.3 Product No. 3}

Blue (front) and grey (back) fabric consisting of wool velvet blend. The product has an area weight of $311 \mathrm{~g} / \mathrm{m}^{2}$.

\section{A.3.1 Application}

The blue (front) side of the fabric was exposed for the burner.

\section{A.3.2 Observations made during fire test}

Test no

Sample dimension, $\mathrm{mm}$

length
width
thickness

Burnt distance, $\mathrm{mm}$

Burning time, $\mathrm{s}$

Burning rate, $\mathrm{mm} / \mathrm{min}$

\section{1}

2

3

4

5

\section{A.3.3 Conditioning}

Temperature $23 \pm 2{ }^{\circ} \mathrm{C}$.

Relative humidity $(50 \pm 5) \%$.

\section{A.3.4 Test conditions}

The combustion chamber was placed in a fume cupboard according to standard.

\section{A.3.5 Date of test}

September 2 and 8, 2009. 


\section{A.4 Product No. 4}

Green (front) and yellow (back) artificial leather consisting of 91.5\% PVC and 8.5\% polyamide. The product has an area weight of $814 \mathrm{~g} / \mathrm{m}^{2}$.

\section{A.4.1 Application}

The green (front) side of the fabric was exposed for the burner.

\section{A.4.2 Observations made during fire test}

Test no

Sample dimension, $\mathrm{mm}$

$\begin{array}{ccccc}\text { length } & 354 & 354 & 354 & 354 \\ \text { width } & 100 & 100 & 100 & 100 \\ \text { thickness } & 1.1 & 1.1 & 1.1 & 1.1 \\ \text { Burnt distance, mm } & -* & -* & -* & -* \\ \text { Burning time, s } & - & - & - & - \\ \text { Burning rate, } \mathrm{mm} / \mathrm{min} & - & - & - & - \\ * \text { In tests no } 1 \text { - } 4 \text { the flames died out before reaching the first measuring point. }\end{array}$

12

2

3

4

\section{A.4.3 Conditioning}

Temperature $23 \pm 2{ }^{\circ} \mathrm{C}$.

Relative humidity $(50 \pm 5) \%$.

\section{A.4.4 Test conditions}

The combustion chamber was placed in a fume cupboard according to standard.

\section{A.4.5 Date of test}

September 2 and 8, 2009. 


\section{A.5 Product No. 5}

Blue (front) and blue/white (back) fabric consisting of $70 \%$ PES and $30 \%$ wool. The product has an area weight of $672 \mathrm{~g} / \mathrm{m}^{2}$.

\section{A.5.1 Application}

The blue (front) side of the fabric was exposed for the burner.

\section{A.5.2 Observations made during fire test}

Test no

Sample dimension, $\mathrm{mm}$

length
width
thickness

Burnt distance, $\mathrm{mm}$

Burning time, $\mathrm{s}$

Burning rate, $\mathrm{mm} / \mathrm{min}$

\section{1}

2

3

4

$\begin{array}{lllll}354 & 354 & 354 & 354 & 354 \\ 100 & 100 & 100 & 100 & 100 \\ 3.2 & 3.2 & 3.2 & 3.2 & 3.2 \\ 254 & 254 & 254 & 254 & 254 \\ 651 & 640 & 652 & 667 & 677 \\ 23.4 & 23.8 & 23.4 & 22.9 & 22.5\end{array}$

\section{A.5.3 Conditioning}

Temperature $23 \pm 2{ }^{\circ} \mathrm{C}$.

Relative humidity $(50 \pm 5) \%$.

\section{A.5.4 Test conditions}

The combustion chamber was placed in a fume cupboard according to standard.

\section{A.5.5 Date of test}

September 2 and 8, 2009. 


\section{A.6 Product No. 6}

Blue (front) and green/black (back) fabric consisting of $55 \%$ polyester and $45 \%$ wool. The product has an area weight of $829 \mathrm{~g} / \mathrm{m}^{2}$.

\section{A.6.1 Application}

The blue (front) side of the fabric was exposed for the burner.

\section{A.6.2 Observations made during fire test}

Test no

Sample dimension, $\mathrm{mm}$

length
width
thickness

Burnt distance, $\mathrm{mm}$

Burning time, $\mathrm{s}$

Burning rate, $\mathrm{mm} / \mathrm{min}$

12

2

3

4

5

* In tests no 1, 2, 3 and 5 the flames died out before reaching the first measuring point.

\section{A.6.3 Conditioning}

Temperature $23 \pm 2{ }^{\circ} \mathrm{C}$.

Relative humidity $(50 \pm 5) \%$.

\section{A.6.4 Test conditions}

The combustion chamber was placed in a fume cupboard according to standard.

\section{A.6.5 Date of test}

September 2 and 8, 2009. 


\section{A.7 Product No. 7}

Dark blue (front) and dark grey (back) fabric consisting of wool velvet blend. The product has an area weight of $974 \mathrm{~g} / \mathrm{m}^{2}$.

\section{A.7.1 Application}

The dark blue (front) side of the fabric was exposed for the burner.

\section{A.7.2 Observations made during fire test}

Test no

Sample dimension, $\mathrm{mm}$

length
width
thickness

Burnt distance, $\mathrm{mm}$

Burning time, $\mathrm{s}$

Burning rate, $\mathrm{mm} / \mathrm{min}$

\section{1}

2

3

4

5

* In tests no 1-5 the flames died out before reaching the first measuring point.

\section{A.7.3 Conditioning}

Temperature $23 \pm 2{ }^{\circ} \mathrm{C}$.

Relative humidity $(50 \pm 5) \%$.

\section{A.7.4 Test conditions}

The combustion chamber was placed in a fume cupboard according to standard.

\section{A.7.5 Date of test}

September 2 and 8, 2009. 


\section{A.8 Product No. 8}

Dark blue (front) and multicoloured (back) fabric consisting of $85 \%$ wool and $15 \%$ nylon. The product has an area weight of $856 \mathrm{~g} / \mathrm{m}^{2}$.

\section{A.8.1 Application}

The dark blue (front) side of the fabric was exposed for the burner.

\section{A.8.2 Observations made during fire test}

Test no

Sample dimension, $\mathrm{mm}$

length
width
thickness

Burnt distance, $\mathrm{mm}$

Burning time, $\mathrm{s}$

Burning rate, $\mathrm{mm} / \mathrm{min}$

12

2

3

4

5

* In tests no 1-5 the flames died out before reaching the first measuring point.

\section{A.8.3 Conditioning}

Temperature $23 \pm 2{ }^{\circ} \mathrm{C}$.

Relative humidity $(50 \pm 5) \%$.

\section{A.8.4 Test conditions}

The combustion chamber was placed in a fume cupboard according to standard.

\section{A.8.5 Date of test}

September 2 and 8, 2009. 


\section{A.9 Product No. 9}

Grey (front) and red/grey (back) fabric consisting of 65\% PES, 20\% wool and 15\% CV. The product has an area weight of $676 \mathrm{~g} / \mathrm{m}^{2}$.

\section{A.9.1 Application}

The grey (front) side of the fabric was exposed for the burner.

\section{A.9.2 Observations made during fire test}

Test no

Sample dimension, $\mathrm{mm}$

length
width
thickness

Burnt distance, $\mathrm{mm}$

Burning time, $\mathrm{s}$

Burning rate, $\mathrm{mm} / \mathrm{min}$

\section{1}

2

3

4

5

$\begin{array}{lllll}354 & 354 & 354 & 354 & 354 \\ 100 & 100 & 100 & 100 & 100 \\ 3.0 & 3.0 & 3.0 & 3.0 & 3.0 \\ 254 & 254 & 254 & 254 & 254 \\ 561 & 547 & 485 & 507 & 566 \\ 27.1 & 27.9 & 31.4 & 30.1 & 26.9\end{array}$

\section{A.9.3 Conditioning}

Temperature $23 \pm 2{ }^{\circ} \mathrm{C}$.

Relative humidity $(50 \pm 5) \%$.

\section{A.9.4 Test conditions}

The combustion chamber was placed in a fume cupboard according to standard.

\section{A.9.5 Date of test}

September 2 and 8, 2009. 


\section{A.10 Product No. 10}

Dark blue (front) and multicoloured (back) fabric consisting of $56 \%$ wool, $35 \%$ cotton and $9 \%$ nylon. The product has an area weight of $826 \mathrm{~g} / \mathrm{m}^{2}$.

\section{A.10.1 Application}

The dark blue (front) side of the fabric was exposed for the burner.

\section{A.10.2 Observations made during fire test}

Test no

Sample dimension, $\mathrm{mm}$

length
width
thickness

Burnt distance, $\mathrm{mm}$

Burning time, $\mathrm{s}$

Burning rate, $\mathrm{mm} / \mathrm{min}$

12

2

3

4

5

* In tests no 1-5 the flames died out before reaching the first measuring point.

\section{A.10.3 Conditioning}

Temperature $23 \pm 2{ }^{\circ} \mathrm{C}$.

Relative humidity $(50 \pm 5) \%$.

\section{A.10.4 Test conditions}

The combustion chamber was placed in a fume cupboard according to standard.

\section{A.10.5 Date of test}

September 2 and 8, 2009. 


\section{A.11 Product No. 11}

Grey needle felt fabric consisting of $100 \%$ polypropylene fibre. The product has an area weight of $510 \mathrm{~g} / \mathrm{m}^{2}$.

\section{A.11.1 Application}

The textured (front) side of the fabric was exposed for the burner.

\section{A.11.2 Observations made during fire test}

Test no

Sample dimension, $\mathrm{mm}$

length
width
thickness

Burnt distance, $\mathrm{mm}$

Burning time, $\mathrm{s}$

Burning rate, $\mathrm{mm} / \mathrm{min}$

\section{1}

2

3

354

100

4.4

254

194

78.6
354

100

4.4

254

198

77.0
354

100

4.4

254

216

70.6
4

5

\section{A.11.3 Conditioning}

Temperature $23 \pm 2{ }^{\circ} \mathrm{C}$.

Relative humidity $(50 \pm 5) \%$.

\section{A.11.4 Test conditions}

The combustion chamber was placed in a fume cupboard according to standard.

\section{A.11.5 Date of test}

September 2 and 8, 2009. 


\section{Appendix B Results vertical burning rate (ISO 6941, ECE Reg No 118 annex 8, directive 95/28/CE annex VI)}

\section{B.1 Product No. 1}

Light grey ABS plastics. The product has an area weight of $3040 \mathrm{~g} / \mathrm{m}^{2}$.

\section{B.1.1 Observations made during fire test}

See Section 2.3 for explanations of the test parameters.

Test no

Sample dimension, $\mathrm{mm}$

$$
\text { length }
$$

width

thickness

Flame exposure time, s

$\mathrm{t}_{1}$

$\mathrm{t}_{2}$

$\mathrm{t}_{3}$

Burning rate $\mathrm{v}_{1}, \mathrm{~mm} / \mathrm{min}$

Burning rate $\mathrm{v}_{2}, \mathrm{~mm} / \mathrm{min}$

Burning rate $\mathrm{v}_{3}, \mathrm{~mm} / \mathrm{min}$

Result $=\max (\mathrm{v} 1, \mathrm{v} 2, \mathrm{v} 3)$,
2 3

1

* In test no 1 the third marker thread never severed. 560 560 170

3.1 15

118 195

195

112

135

140

$\begin{array}{lll}178 & 135 & 140\end{array}$

$160 \quad 172$

\section{B.1.2 Conditioning}

Temperature $23 \pm 2{ }^{\circ} \mathrm{C}$.

Relative humidity $(50 \pm 5) \%$.

\section{B.1.3 Test conditions}

The combustion chamber was placed in a fume cupboard according to standard.

\section{B.1.4 Date of test}

September 7 and 9, 2009. 


\section{B.2 Product No. 2}

Dark grey Perstorp Compactlaminate consisting of paper-reinforced thermosetting plastic (two-side high pressure laminate). The product is used in partitions. The product has an area weight of $8780 \mathrm{~g} / \mathrm{m}^{2}$.

\section{B.2.1 Observations made during fire test}

See Section 2.3 for explanations of the test parameters.

Test no

1

2

3

Sample dimension, $\mathrm{mm}$

$\begin{array}{lccc}\text { length } & 560 & 560 & 560 \\ \text { width } & 170 & 170 & 170 \\ \text { thickness } & 5.8 & 5.8 & 5.8\end{array}$

Flame exposure time, $s \quad 15-15$

$\mathrm{t}_{1}$

$\mathrm{t}_{2}$

$t_{3}$

Burning rate $\mathrm{v}_{1}, \mathrm{~mm} / \mathrm{min}$

Burning rate $\mathrm{v}_{2}, \mathrm{~mm} / \mathrm{min}$

Burning rate $\mathrm{v}_{3}, \mathrm{~mm} / \mathrm{min}$

Result $=\max (\mathrm{v} 1, \mathrm{v} 2, \mathrm{v} 3)$,

* In tests no 1-2 the marker threads never severed.

\section{B.2.2 Conditioning}

Temperature $23 \pm 2{ }^{\circ} \mathrm{C}$.

Relative humidity $(50 \pm 5) \%$.

\section{B.2.3 Test conditions}

The combustion chamber was placed in a fume cupboard according to standard.

\section{B.2.4 Date of test}

September 7 and 10, 2009. 


\section{B.3 Product No. 3}

Blue (front) and grey (back) fabric consisting of wool velvet blend. The product has an area weight of $311 \mathrm{~g} / \mathrm{m}^{2}$.

\section{B.3.1 Observations made during fire test}

See Section 2.3 for explanations of the test parameters.

Test no

1

2

3

4

Sample dimension, $\mathrm{mm}$

$\begin{array}{lllll}\text { length } & 560 & 560 & 560 & 560 \\ \text { width } & 170 & 170 & 170 & 170 \\ \text { thickness } & 2.8 & 2.8 & 2.8 & 2.8\end{array}$

$\begin{array}{lllll}\text { Flame exposure time, } \mathrm{s} & 5 & 15 & 15 & 15 \\ \mathrm{t}_{1} & -* & -* & -* & -* \\ \mathrm{t}_{2} & -* & -* & -* & -* \\ \mathrm{t}_{3} & -* & -* & -* & -* \\ \text { Burning rate } \mathrm{v}_{1}, \mathrm{~mm} / \mathrm{min} & - & - & - & - \\ \text { Burning rate } \mathrm{v}_{2}, \mathrm{~mm} / \mathrm{min} & - & - & - \\ \text { Burning rate } \mathrm{v}_{3}, \mathrm{~mm} / \mathrm{min} & - & - & - & - \\ \text { Result }=\max (\mathrm{v} 1, \mathrm{v} 2, \mathrm{v} 3), & - & - & -\end{array}$

\section{B.3.2 Conditioning}

Temperature $23 \pm 2{ }^{\circ} \mathrm{C}$.

Relative humidity $(50 \pm 5) \%$.

\section{B.3.3 Test conditions}

The combustion chamber was placed in a fume cupboard according to standard.

\section{B.3.4 Date of test}

September 7 and 10, 2009. 


\section{B.4 Product No. 4}

Green (front) and yellow (back) artificial leather consisting of 91.5\% PVC and 8.5\% polyamide. The product has an area weight of $814 \mathrm{~g} / \mathrm{m}^{2}$.

\section{B.4.1 Observations made during fire test}

See Section 2.3 for explanations of the test parameters.

Test no

Sample dimension, $\mathrm{mm}$

length

width

thickness

Flame exposure time, s

$\mathrm{t}_{1}$

$t_{2}$

$t_{3}$

Burning rate $\mathrm{v}_{1}, \mathrm{~mm} / \mathrm{min}$

Burning rate $\mathrm{v}_{2}, \mathrm{~mm} / \mathrm{min}$

Burning rate $\mathrm{v}_{3}, \mathrm{~mm} / \mathrm{min}$

Result $=\max (\mathrm{v} 1, \mathrm{v} 2, \mathrm{v} 3)$,

* In tests no 1-3 the marker threads never severed.

\section{B.4.2 Conditioning}

Temperature $23 \pm 2{ }^{\circ} \mathrm{C}$.

Relative humidity $(50 \pm 5) \%$.

\section{B.4.3 Test conditions}

The combustion chamber was placed in a fume cupboard according to standard.

\section{B.4.4 Date of test}

September 7 and 10, 2009. 


\section{B.5 Product No. 5}

Blue (front) and blue/white (back) fabric consisting of 70\% PES and 30\% wool. The product has an area weight of $672 \mathrm{~g} / \mathrm{m}^{2}$.

\section{B.5.1 Observations made during fire test}

See Section 2.3 for explanations of the test parameters.

Test no

Sample dimension, $\mathrm{mm}$

length

width

thickness

Flame exposure time, $\mathrm{s}$

$\mathrm{t}_{1}$

$t_{2}$

$t_{3}$

Burning rate $\mathrm{v}_{1}, \mathrm{~mm} / \mathrm{min}$

Burning rate $\mathrm{v}_{2}, \mathrm{~mm} / \mathrm{min}$

Burning rate $\mathrm{v}_{3}, \mathrm{~mm} / \mathrm{min}$

Result $=\max (\mathrm{v} 1, \mathrm{v} 2, \mathrm{v} 3)$,
578

578

2

3

$560 \quad 560 \quad 560$

$\begin{array}{lll}170 & 170 & 170\end{array}$

$\begin{array}{lll}3.2 & 3.2 & 3.2\end{array}$

$\begin{array}{lll}15 & 15\end{array}$

$\begin{array}{lll}35 & 35 & 41\end{array}$

$\begin{array}{lll}54 & 53 & 61\end{array}$

$\begin{array}{lll}58 & 59 & 69\end{array}$

$\begin{array}{lll}377 & 377 & 322\end{array}$

$\begin{array}{lll}411 & 419 & 364\end{array}$

$529 \quad 452$

529

452

\section{B.5.2 Conditioning}

Temperature $23 \pm 2{ }^{\circ} \mathrm{C}$.

Relative humidity $(50 \pm 5) \%$.

\section{B.5.3 Test conditions}

The combustion chamber was placed in a fume cupboard according to standard.

\section{B.5.4 Date of test}

September 7 and 10, 2009. 


\section{B.6 Product No. 6}

Blue (front) and green/black (back) fabric consisting of $55 \%$ polyester and $45 \%$ wool. The product has an area weight of $829 \mathrm{~g} / \mathrm{m}^{2}$.

\section{B.6.1 Observations made during fire test}

See Section 2.3 for explanations of the test parameters.

Test no

Sample dimension, $\mathrm{mm}$

length

width

thickness

Flame exposure time, $\mathrm{s}$

$\mathrm{t}_{1}$

$\mathrm{t}_{2}$

$t_{3}$

Burning rate $\mathrm{v}_{1}, \mathrm{~mm} / \mathrm{min}$

Burning rate $\mathrm{v}_{2}, \mathrm{~mm} / \mathrm{min}$

Result $=\max (\mathrm{v} 1, \mathrm{v} 2, \mathrm{v} 3)$

427

255

\section{B.6.2 Conditioning}

Temperature $23 \pm 2{ }^{\circ} \mathrm{C}$.

Relative humidity $(50 \pm 5) \%$.

\section{B.6.3 Test conditions}

The combustion chamber was placed in a fume cupboard according to standard.

\section{B.6.4 Date of test}

September 7 and 9, 2009. 


\section{B.7 Product No. 7}

Dark blue (front) and dark grey (back) fabric consisting of wool velvet blend. The product has an area weight of $974 \mathrm{~g} / \mathrm{m}^{2}$.

\section{B.7.1 Observations made during fire test}

See Section 2.3 for explanations of the test parameters.

Test no

1

2

3

Sample dimension, $\mathrm{mm}$

$\begin{array}{lccc}\text { length } & 560 & 560 & 560 \\ \text { width } & 170 & 170 & 170 \\ \text { thickness } & 4.4 & 4.4 & 4.4\end{array}$

$\begin{array}{lccc}\text { Flame exposure time, } \mathrm{s} & 15 & 15 & 15 \\ \mathrm{t}_{1} & -* & 60 & -* \\ \mathrm{t}_{2} & -* & 107 & -* \\ \mathrm{t}_{3} & -* & 119 & -* \\ \text { Burning rate } \mathrm{v}_{1}, \mathrm{~mm} / \mathrm{min} & - & 220 & - \\ \text { Burning rate } \mathrm{v}_{2}, \mathrm{~mm} / \mathrm{min} & - & 207 & - \\ \text { Burning rate } \mathrm{v}_{3}, \mathrm{~mm} / \mathrm{min} & - & 262 & - \\ & & & \\ \text { Result }=\max (\mathrm{v} 1, \mathrm{v} 2, \mathrm{v} 3), & - & 262\end{array}$

\section{B.7.2 Conditioning}

Temperature $23 \pm 2{ }^{\circ} \mathrm{C}$.

Relative humidity $(50 \pm 5) \%$.

\section{B.7.3 Test conditions}

The combustion chamber was placed in a fume cupboard according to standard.

\section{B.7.4 Date of test}

September 7 and 9, 2009. 


\section{B.8 Product No. 8}

Dark blue (front) and multicoloured (back) fabric consisting of $85 \%$ wool and $15 \%$ nylon. The product has an area weight of $856 \mathrm{~g} / \mathrm{m}^{2}$.

\section{B.8.1 Observations made during fire test}

See Section 2.3 for explanations of the test parameters.

Test no

Sample dimension, $\mathrm{mm}$

length

width

thickness

Flame exposure time, $\mathrm{s}$

$\mathrm{t}_{1}$

$t_{2}$

$t_{3}$

Burning rate $\mathrm{v}_{1}, \mathrm{~mm} / \mathrm{min}$

Burning rate $\mathrm{v}_{2}, \mathrm{~mm} / \mathrm{min}$

Burning rate $\mathrm{v}_{3}, \mathrm{~mm} / \mathrm{min}$

Result $=\max (\mathrm{v} 1, \mathrm{v} 2, \mathrm{v} 3)$,

* In tests no 1 and 3 the marker threads never severed.

\section{B.8.2 Conditioning}

Temperature $23 \pm 2{ }^{\circ} \mathrm{C}$.

Relative humidity $(50 \pm 5) \%$.

\section{B.8.3 Test conditions}

The combustion chamber was placed in a fume cupboard according to standard.

\section{B.8.4 Date of test}

September 7 and 9, 2009. 


\section{B.9 Product No. 9}

Grey (front) and red/grey (back) fabric consisting of 65\% PES, 20\% wool and 15\% CV. The product has an area weight of $676 \mathrm{~g} / \mathrm{m}^{2}$.

\section{B.9.1 Observations made during fire test}

See Section 2.3 for explanations of the test parameters.

Test no

Sample dimension, $\mathrm{mm}$

length

width

thickness

Flame exposure time, $\mathrm{s}$

$\mathrm{t}_{1}$

$\mathrm{t}_{2}$

$t_{3}$

Burning rate $\mathrm{v}_{1}, \mathrm{~mm} / \mathrm{min}$

Burning rate $\mathrm{v}_{2}, \mathrm{~mm} / \mathrm{min}$

Burning rate $\mathrm{v}_{3}, \mathrm{~mm} / \mathrm{min}$

Result $=\max (\mathrm{v} 1, \mathrm{v} 2, \mathrm{v} 3)$
495

2

3

$560 \quad 560 \quad 560$

$\begin{array}{lll}170 & 170 & 170\end{array}$

$\begin{array}{lll}3.0 & 3.0 & 3.0\end{array}$

$15 \quad 15$

$\begin{array}{ll}30 & 46\end{array}$

$\begin{array}{lll}44 & 56 & 46\end{array}$

$63 \quad 68 \quad 65$

$\begin{array}{lll}440 & 289 & 367\end{array}$

$505 \quad 396 \quad 483$

$459 \quad 480$

$459 \quad 480$

\section{B.9.2 Conditioning}

Temperature $23 \pm 2{ }^{\circ} \mathrm{C}$.

Relative humidity $(50 \pm 5) \%$.

\section{B.9.3 Test conditions}

The combustion chamber was placed in a fume cupboard according to standard.

\section{B.9.4 Date of test}

September 7 and 10, 2009. 


\section{B.10 Product No. 10}

Dark blue (front) and multicoloured (back) fabric consisting of $56 \%$ wool, $35 \%$ cotton and $9 \%$ nylon. The product has an area weight of $826 \mathrm{~g} / \mathrm{m}^{2}$.

\section{B.10.1 Observations made during fire test}

See Section 2.3 for explanations of the test parameters.

Test no

1

2

3

Sample dimension, $\mathrm{mm}$

$\begin{array}{llll}\text { length } & 560 & 560 & 560 \\ \text { width } & 170 & 170 & 170 \\ \text { thickness } & 4.2 & 4.2 & 4.2 \\ \text { Flame exposure time, s } & 15 & 15 & 15 \\ \mathrm{t}_{1} & -* & -* & -* \\ \mathrm{t}_{2} & -* & -* & -* \\ \mathrm{t}_{3} & -* & -* & -* \\ \text { Burning rate } \mathrm{v}_{1}, \mathrm{~mm} / \mathrm{min} & - & - & - \\ \text { Burning rate } \mathrm{v}_{2}, \mathrm{~mm} / \mathrm{min} & - & - & - \\ \text { Burning rate } \mathrm{v}_{3}, \mathrm{~mm} / \mathrm{min} & - & - & - \\ \text { Result }=\max (\mathrm{v} 1, \mathrm{v} 2, \mathrm{v} 3), & - & - & - \\ * \text { In tests no 1-3 the marker threads never severed. }\end{array}$

\section{B.10.2 Conditioning}

Temperature $23 \pm 2{ }^{\circ} \mathrm{C}$.

Relative humidity $(50 \pm 5) \%$.

\section{B.10.3 Test conditions}

The combustion chamber was placed in a fume cupboard according to standard.

\section{B.10.4 Date of test}

September 7 and 10, 2009. 


\section{B.11 Product No. 11}

Grey needle felt fabric consisting of $100 \%$ polypropylene fibre. The product has an area weight of $510 \mathrm{~g} / \mathrm{m}^{2}$.

\section{B.11.1 Observations made during fire test}

See Section 2.3 for explanations of the test parameters.

Test no

Sample dimension, $\mathrm{mm}$

length

width

thickness

Flame exposure time, $\mathrm{s}$

$\mathrm{t}_{1}$

$\mathrm{t}_{2}$

$t_{3}$

Burning rate $\mathrm{v}_{1}, \mathrm{~mm} / \mathrm{min}$

Burning rate $\mathrm{v}_{2}, \mathrm{~mm} / \mathrm{min}$

Burning rate $\mathrm{v}_{3}, \mathrm{~mm} / \mathrm{min}$

Result $=\max (\mathrm{v} 1, \mathrm{v} 2, \mathrm{v} 3)$

103

* In test no 2 the third marker thread never severed.

** In test no 3 the second and third marker threads never severed.

\section{B.11.2 Conditioning}

Temperature $23 \pm 2{ }^{\circ} \mathrm{C}$.

Relative humidity $(50 \pm 5) \%$.

\section{B.11.3 Test conditions}

The combustion chamber was placed in a fume cupboard according to standard.

\section{B.11.4 Date of test}

September 7 and 9, 2009. 


\section{Appendix C Results Spread of Flame, SoF (ISO 5658-2)}

\section{C.1 Product No. 1}

Light grey ABS plastics. The product has an area weight of $3040 \mathrm{~g} / \mathrm{m}^{2}$.

\section{C.1.1 Observations made during fire test}

\begin{tabular}{|l|c|c|}
\hline Test no & 1 & 2 \\
\hline $\begin{array}{l}\text { Flames at flame } \\
\text { front went out }\end{array}$ & $32: 00$ at $800 \mathrm{~mm}$ & $30: 00$ at $800 \mathrm{~mm}$ \\
\hline Burning droplets & none & none \\
\hline
\end{tabular}

\section{C.1.2 Derived fire characteristics}

\begin{tabular}{|l|c|c|c|c|c|}
\hline Test no & 1 & 2 & & Average & $\begin{array}{l}\text { Surface } \\
\text { flammability } \\
\text { criteria }\end{array}$ \\
\hline Heat for ignition, $\mathrm{MJ} / \mathrm{m}^{2}$ & 1.8 & 1.9 & & $\underline{1.8}$ & - \\
\hline $\begin{array}{l}\text { Avera ge heat for sustained } \\
\text { burning, } \mathrm{Q}_{\mathrm{sb}}, \mathrm{MJ} / \mathrm{m}^{2}\end{array}$ & 2.1 & 2.1 & & $\underline{2.1}$ & $\geq 1.5$ \\
\hline $\begin{array}{l}\text { Critical flux at extinguishement, } \\
\mathrm{CFE}, \mathrm{kW} / \mathrm{m}^{2}\end{array}$ & 1.5 & 1.8 & & $\underline{1.6}$ & $\geq 20.0$ \\
\hline Total heat release, $\mathrm{Q}_{\mathrm{t}}, \mathrm{MJ}$ & 4.7 & 5.3 & & $\underline{5}$ & $\leq 0.7$ \\
\hline Peak heat release rate, $\mathrm{Q}_{\mathrm{p}}, \mathrm{kW}$ & 17.6 & 17.8 & & $\underline{17.7}$ & $\leq 4.0$ \\
\hline
\end{tabular}




\section{C.1.3 Heat release rates, graphs}

Test 1

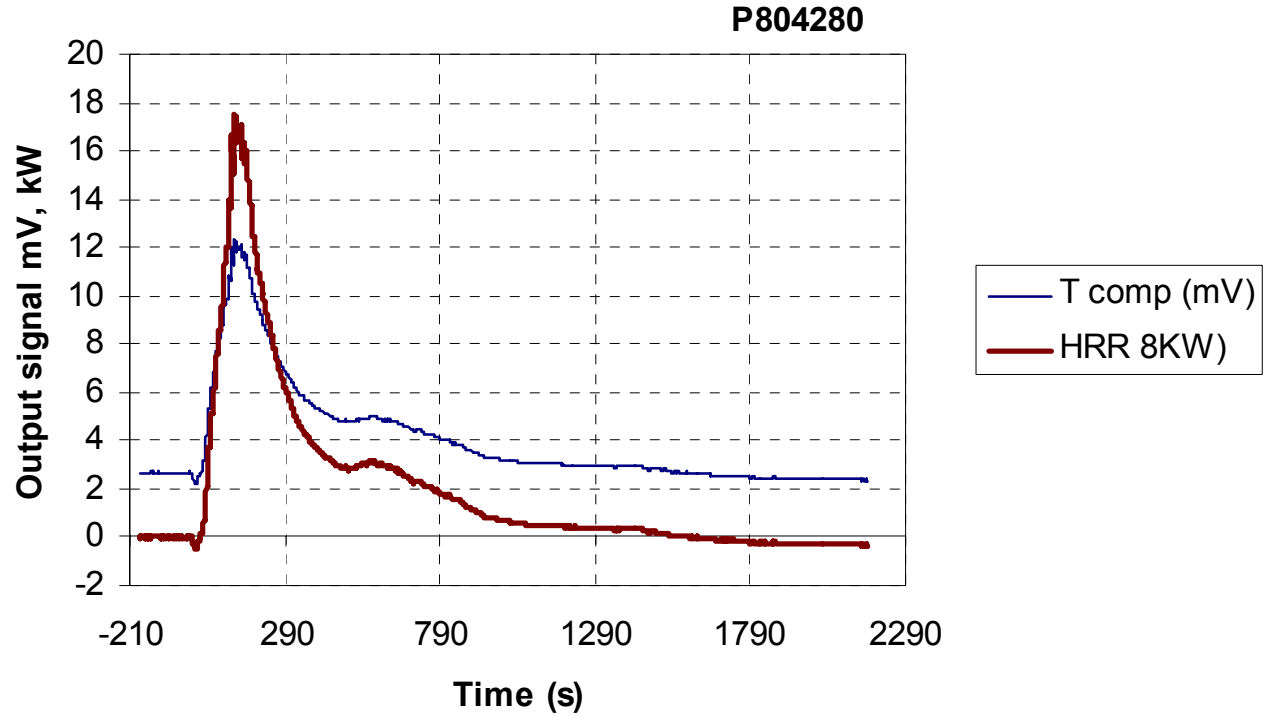

Figure 1 Heat release rate for test no 1 .

Total heat release: 4.7 MJ. Peak heat release rate: $17.6 \mathrm{~kW}$.

Test 2

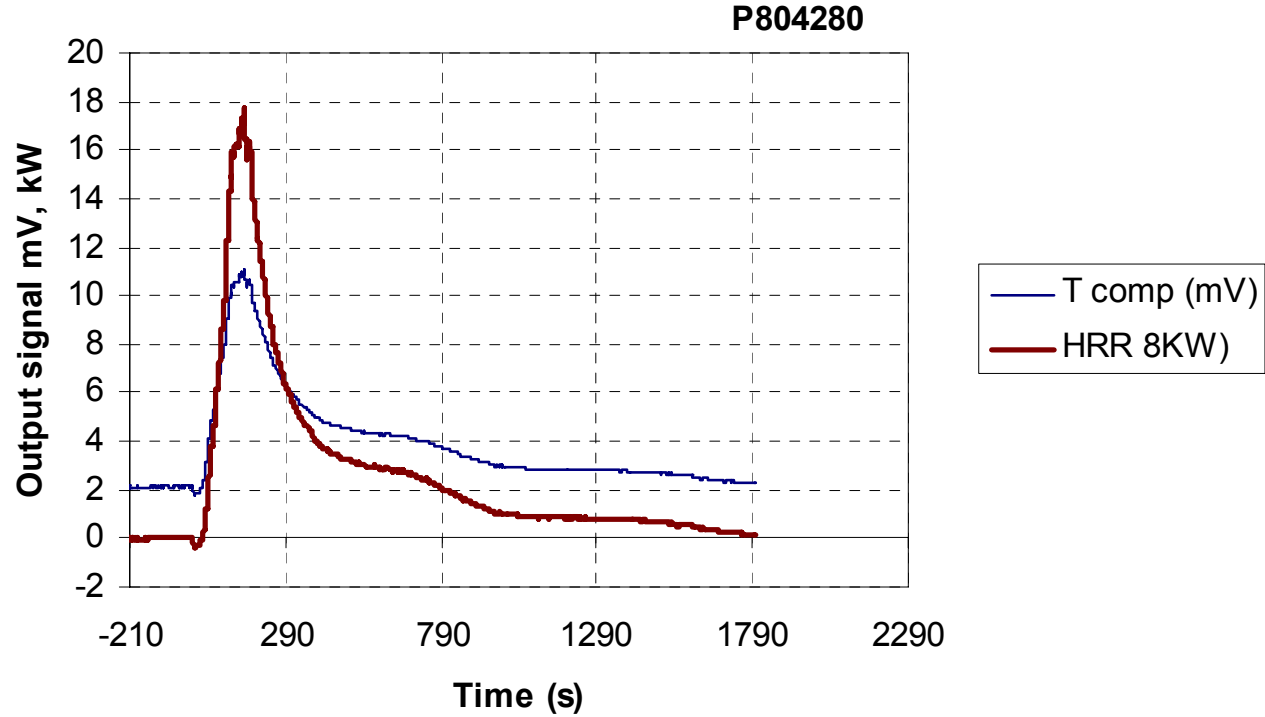

Figure 2 Heat release rate for test no 2.

Total heat release: 5.3 MJ. Peak heat release rate: $17.8 \mathrm{~kW}$. 


\section{C.1.4 Conditioning}

Temperature $23 \pm 2{ }^{\circ} \mathrm{C}$.

Relative humidity $(50 \pm 5) \%$.

\section{C.1.5 Date of test}

September 4 and October 1, 2009. 


\section{C.2 Product No. 2}

Dark grey Perstorp Compactlaminate consisting of paper-reinforced thermosetting plastic (two-side high pressure laminate). The product is used in partitions. The product has an area weight of $8780 \mathrm{~g} / \mathrm{m}^{2}$.

\section{C.2.1 Observations made during fire test}

\begin{tabular}{|l|c|c|}
\hline Test no & 1 & 2 \\
\hline $\begin{array}{l}\text { Flames at flame } \\
\text { front went out }\end{array}$ & $12: 35$ at $380 \mathrm{~mm}$ & $07: 30$ at $340 \mathrm{~mm}$ \\
\hline Burning droplets & none & none \\
\hline
\end{tabular}

\section{C.2.2 Derived fire characteristics}

\begin{tabular}{|l|c|c|c|c|c|}
\hline Test no & 1 & 2 & & Average & $\begin{array}{l}\text { Surface } \\
\text { flammability } \\
\text { criteria }\end{array}$ \\
\hline Heat for ignition, $\mathrm{MJ} / \mathrm{m}^{2}$ & 2.9 & 2.6 & & $\underline{2.8}$ & - \\
\hline $\begin{array}{l}\text { Avera ge heat for sustained } \\
\text { burning, } \mathrm{Q}_{\mathrm{sb}}, \mathrm{MJ} / \mathrm{m}^{2}\end{array}$ & 4 & 3.5 & $\underline{3.7}$ & $\geq 1.5$ \\
\hline $\begin{array}{l}\text { Critical flux at extinguishement, } \\
\text { CFE, } \mathrm{kW} / \mathrm{m}^{2}\end{array}$ & 20.5 & 25.1 & & $\underline{22.8}$ & $\geq 20.0$ \\
\hline Total heat release, $\mathrm{Q}_{\mathrm{t}}, \mathrm{MJ}$ & 3.3 & 3.4 & & $\underline{3.3}$ & $\leq 0.7$ \\
\hline Peak heat release rate, $\mathrm{Q}_{\mathrm{p}}, \mathrm{kW}$ & 3.3 & 4.6 & & $\underline{3.9}$ & $\leq 4.0$ \\
\hline
\end{tabular}




\section{C.2.3 Heat release rates, graphs}

Test 1

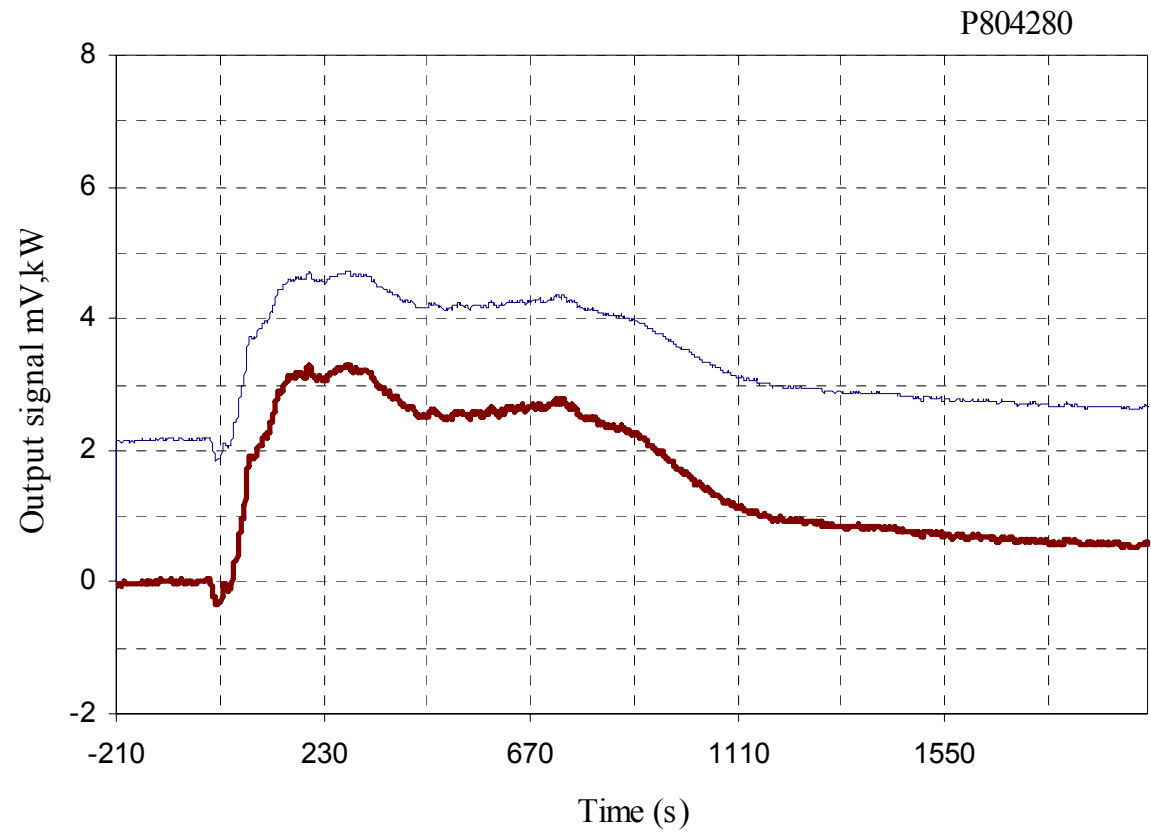

Figure $1 \quad$ Heat release rate for test no 1.

Total heat release: $3.3 \mathrm{MJ}$. Peak heat release rate: $3.3 \mathrm{~kW}$.

Test 2

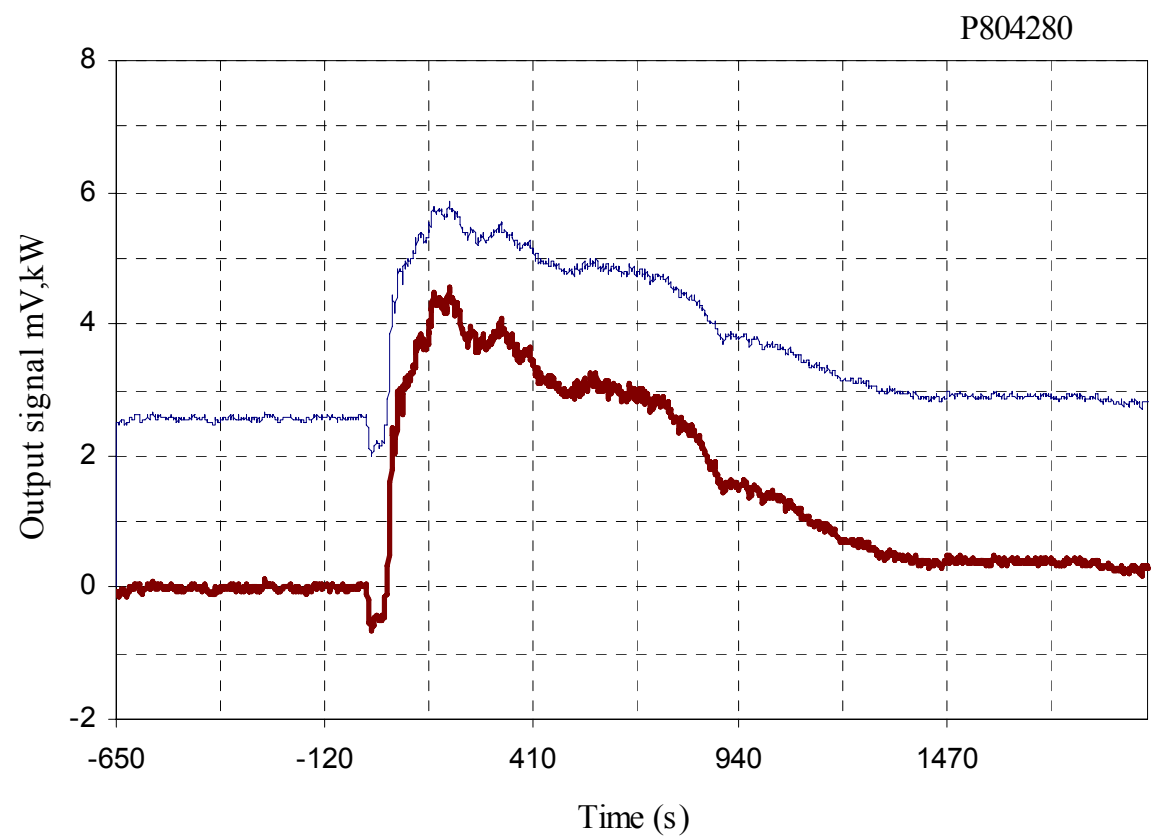

Figure 2 Heat release rate for test no 2.

Total heat release: 3.4 MJ. Peak heat release rate: $4.6 \mathrm{~kW}$. 


\section{C.2.4 Conditioning}

Temperature $23 \pm 2{ }^{\circ} \mathrm{C}$.

Relative humidity $(50 \pm 5) \%$.

\section{C.2.5 Date of test}

September 4 and 8, 2009. 


\section{C.3 Product No. 3}

Blue (front) and grey (back) fabric consisting of wool velvet blend. The product has an area weight of $311 \mathrm{~g} / \mathrm{m}^{2}$.

\section{C.3.1 Observations made during fire test}

\begin{tabular}{|l|c|c|}
\hline Test no & 1 & 2 \\
\hline $\begin{array}{l}\text { Flames at flame } \\
\text { front went out }\end{array}$ & $04: 40$ at $800 \mathrm{~mm}$ & $03: 40$ at $680 \mathrm{~mm}$ \\
\hline Burning droplets & none & none \\
\hline
\end{tabular}

\section{C.3.2 Derived fire characteristics}

\begin{tabular}{|l|c|c|c|c|c|}
\hline Test no & 1 & 2 & & Average & $\begin{array}{l}\text { Surface } \\
\text { flammability } \\
\text { criteria }\end{array}$ \\
\hline Heat for ignition, $\mathrm{MJ} / \mathrm{m}^{2}$ & 0.1 & 0.2 & & $\underline{0.2}$ & - \\
\hline $\begin{array}{l}\text { Avera ge heat for sustained } \\
\text { burning, } \mathrm{Q}_{\mathrm{sb}}, \mathrm{MJ} / \mathrm{m}^{2}\end{array}$ & 0.3 & 0.3 & & $\underline{0.3}$ & $\geq 1.5$ \\
\hline $\begin{array}{l}\text { Critical flux at extinguishement, } \\
\text { CFE, } \mathrm{kW} / \mathrm{m}^{2}\end{array}$ & 1.5 & 2.7 & & $\underline{2.1}$ & $\geq 20.0$ \\
\hline Total heat release, $\mathrm{Q}_{\mathrm{t}}, \mathrm{MJ}$ & 0.1 & $<0.1$ & & $\underline{\leq 0.1}$ & $\leq 0.7$ \\
\hline Peak heat release rate, $\mathrm{Q}_{\mathrm{p}}, \mathrm{kW}$ & 1 & 0.9 & & $\underline{0.9}$ & $\leq 4.0$ \\
\hline
\end{tabular}




\section{C.3.3 Heat release rates, graphs}

Test 1

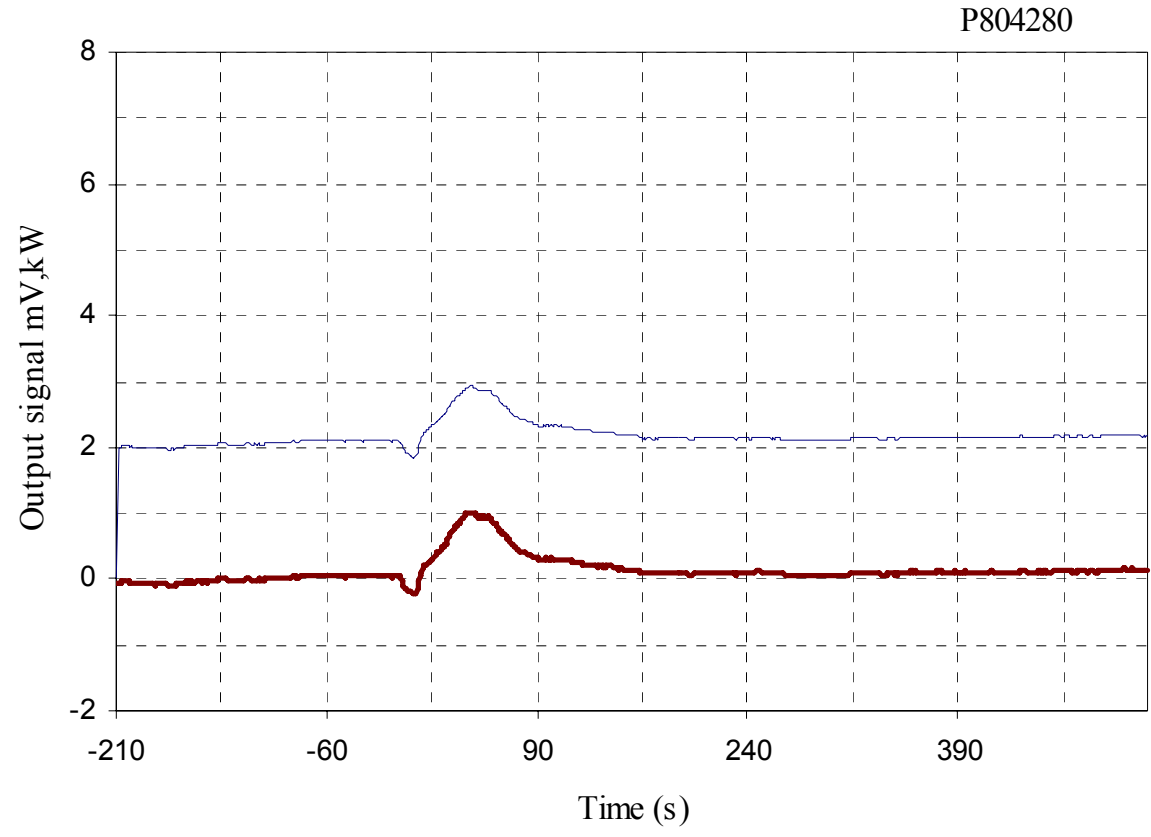

Figure $1 \quad$ Heat release rate for test no 1.

Total heat release: 0.1 MJ. Peak heat release rate: $1.0 \mathrm{~kW}$.

Test 2

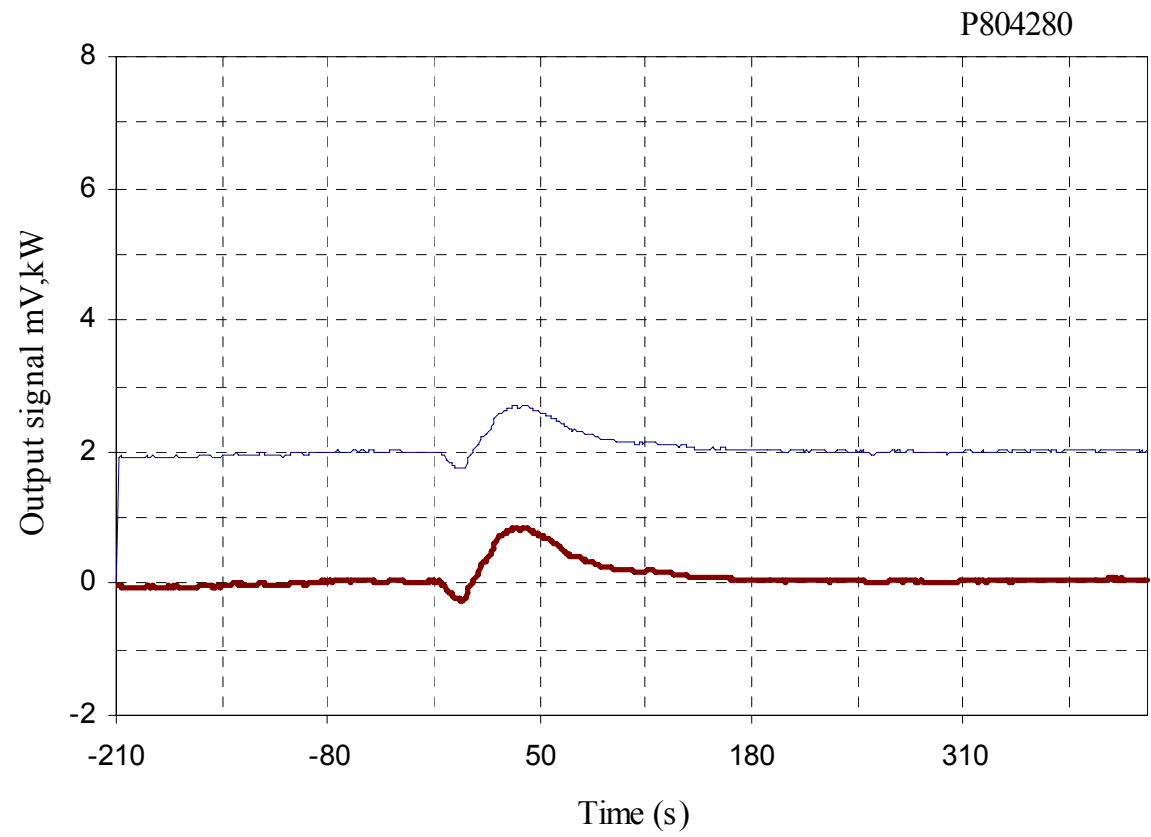

Figure $2 \quad$ Heat release rate for test no 2.

Total heat release: $<0.1$ MJ. Peak heat release rate: $0.9 \mathrm{~kW}$. 


\section{C.3.4 Conditioning}

Temperature $23 \pm 2{ }^{\circ} \mathrm{C}$.

Relative humidity $(50 \pm 5) \%$.

\section{C.3.5 Date of test}

September 4 and 29, 2009. 


\section{C.4 Product No. 4}

Green (front) and yellow (back) artificial leather consisting of 91.5\% PVC and 8.5\% polyamide. The product has an area weight of $814 \mathrm{~g} / \mathrm{m}^{2}$.

\section{C.4.1 Observations made during fire test}

\begin{tabular}{|l|c|c|}
\hline Test no & 1 & 2 \\
\hline $\begin{array}{l}\text { Flames at flame } \\
\text { front went out }\end{array}$ & $01: 53$ at $400 \mathrm{~mm}$ & $02: 00$ at $420 \mathrm{~mm}$ \\
\hline Burning droplets & none & none \\
\hline
\end{tabular}

\section{C.4.2 Derived fire characteristics}

\begin{tabular}{|l|c|c|c|c|c|}
\hline Test no & 1 & 2 & & Average & $\begin{array}{l}\text { Surface } \\
\text { flammability } \\
\text { criteria }\end{array}$ \\
\hline Heat for ignition, $\mathrm{MJ} / \mathrm{m}^{2}$ & 0.2 & 0.3 & & $\underline{0.2}$ & - \\
\hline $\begin{array}{l}\text { Avera ge heat for sustained } \\
\text { burning, } \mathrm{Q}_{\mathrm{sb}}, \mathrm{MJ} / \mathrm{m}^{2}\end{array}$ & 0.7 & 0.5 & & $\underline{0.6}$ & $\geq 1.5$ \\
\hline $\begin{array}{l}\text { Critical } \mathrm{flux} \text { at extinguishement, } \\
\text { CFE, } \mathrm{kW} / \mathrm{m}^{2}\end{array}$ & 18.3 & 16.7 & & $\underline{17.5}$ & $\geq 20.0$ \\
\hline Total heat release, $\mathrm{Q}_{\mathrm{t}}, \mathrm{MJ}$ & 0.3 & 0.2 & & $\underline{0.3}$ & $\leq 0.7$ \\
\hline Peak heat release rate, $\mathrm{Q}_{\mathrm{p}}, \mathrm{kW}$ & 4.7 & 2.8 & & $\underline{3.7}$ & $\leq 4.0$ \\
\hline
\end{tabular}




\section{C.4.3 Heat release rates, graphs}

Test 1

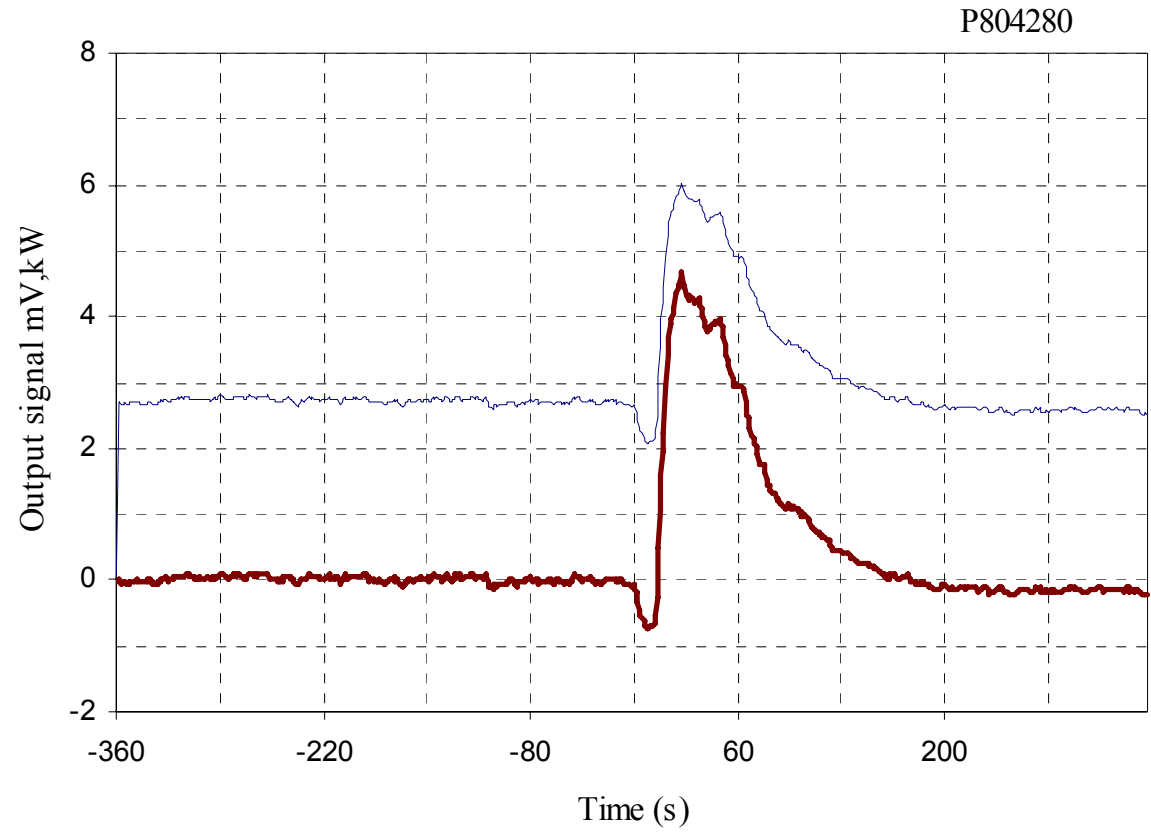

Figure $1 \quad$ Heat release rate for test no 1 .

Total heat release: 0.3 MJ. Peak heat release rate: $4.7 \mathrm{~kW}$.

Test 2

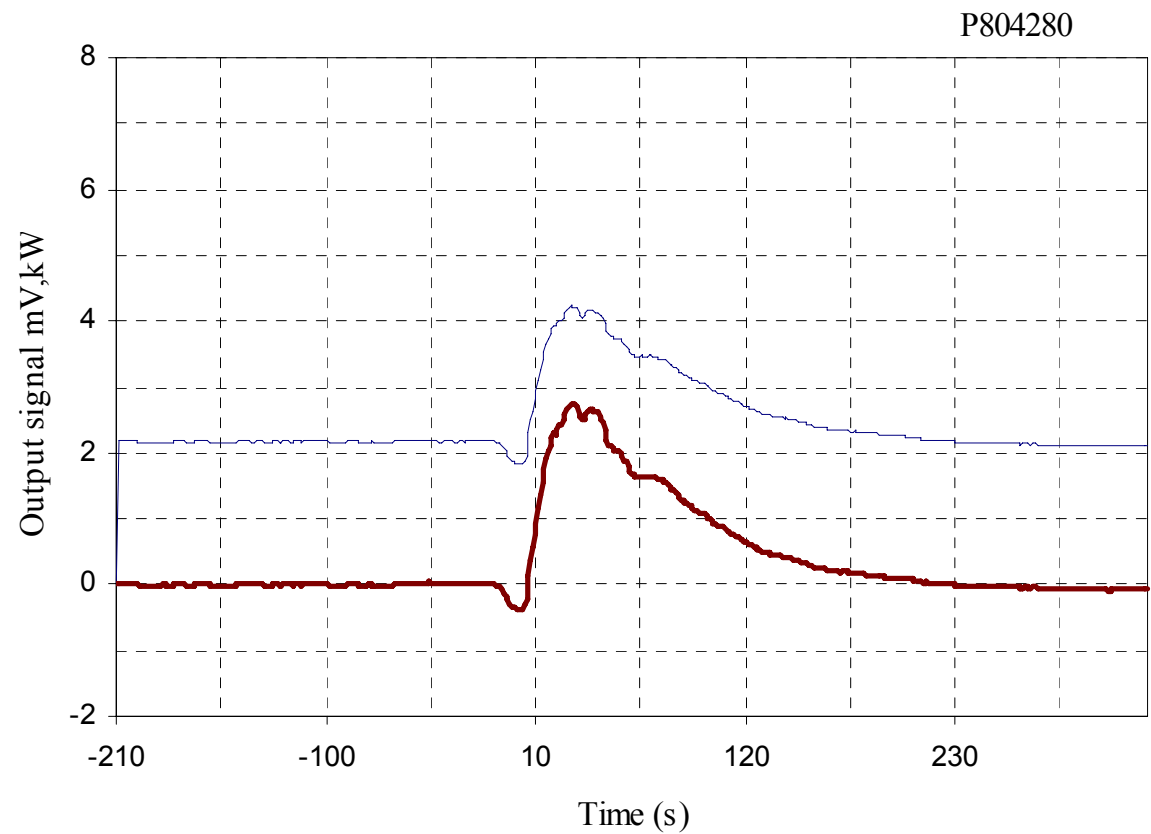

Figure 2 Heat release rate for test no 2.

Total heat release: $0.2 \mathrm{MJ}$. Peak heat release rate: $2.8 \mathrm{~kW}$. 


\section{C.4.4 Conditioning}

Temperature $23 \pm 2{ }^{\circ} \mathrm{C}$.

Relative humidity $(50 \pm 5) \%$.

\section{C.4.5 Date of test}

September 8 and 29, 2009. 


\section{C.5 Product No. 5}

Blue (front) and blue/white (back) fabric consisting of 70\% PES and 30\% wool. The product has an area weight of $672 \mathrm{~g} / \mathrm{m}^{2}$.

\section{C.5.1 Observations made during fire test}

\begin{tabular}{|l|c|c|}
\hline Test no & 1 & 2 \\
\hline $\begin{array}{l}\text { Flames at flame } \\
\text { front went out }\end{array}$ & $04: 46$ at $470 \mathrm{~mm}$ & $04: 04$ at $470 \mathrm{~mm}$ \\
\hline Burning droplets & none & none \\
\hline
\end{tabular}

\section{C.5.2 Derived fire characteristics}

\begin{tabular}{|l|c|c|c|c|c|}
\hline Test no & 1 & 2 & & Average & $\begin{array}{l}\text { Surface } \\
\text { flammability } \\
\text { criteria }\end{array}$ \\
\hline Heat for ignition, MJ/m ${ }^{2}$ & 0.6 & 0.5 & & $\underline{0.5}$ & - \\
\hline $\begin{array}{l}\text { Avera ge heat for sustained } \\
\text { burning, } \mathrm{Q}_{\mathrm{sb}}, \mathrm{MJ} / \mathrm{m}^{2}\end{array}$ & 1.1 & 1.1 & $\underline{1.1}$ & $\geq 1.5$ \\
\hline $\begin{array}{l}\text { Critical } \mathrm{flux} \text { at extinguishement, } \\
\text { CFE, } \mathrm{kW} / \mathrm{m}^{2}\end{array}$ & 11.9 & 12.2 & & $\underline{12}$ & $\geq 20.0$ \\
\hline Total heat release, $\mathrm{Q}_{\mathrm{t}}, \mathrm{MJ}$ & 0.4 & 0.4 & & $\underline{0.4}$ & $\leq 0.7$ \\
\hline Peak heat release rate, $\mathrm{Q}_{\mathrm{p}}, \mathrm{kW}$ & 6 & 3.7 & & $\underline{4.9}$ & $\leq 4.0$ \\
\hline
\end{tabular}




\section{C.5.3 Heat release rates, graphs}

Test 1

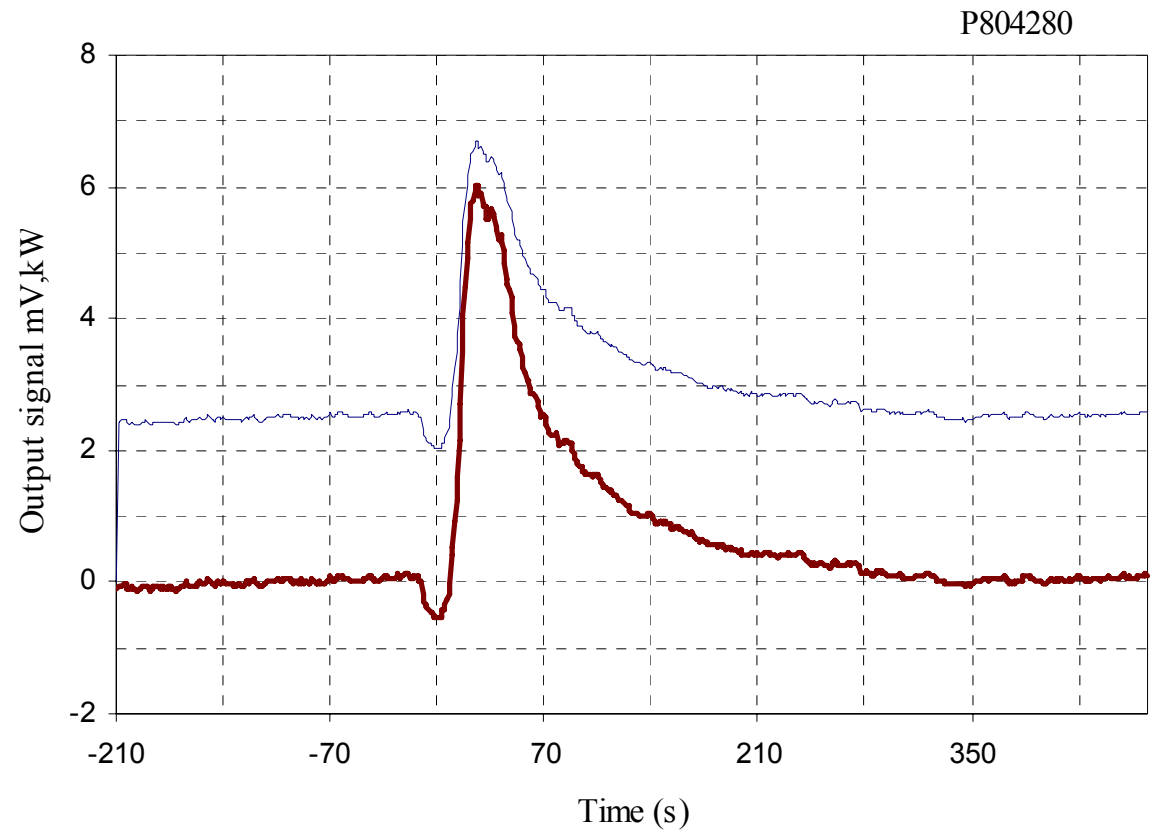

Figure $1 \quad$ Heat release rate for test no 1 .

Total heat release: 0.4 MJ. Peak heat release rate: $6.0 \mathrm{~kW}$.

Test 2

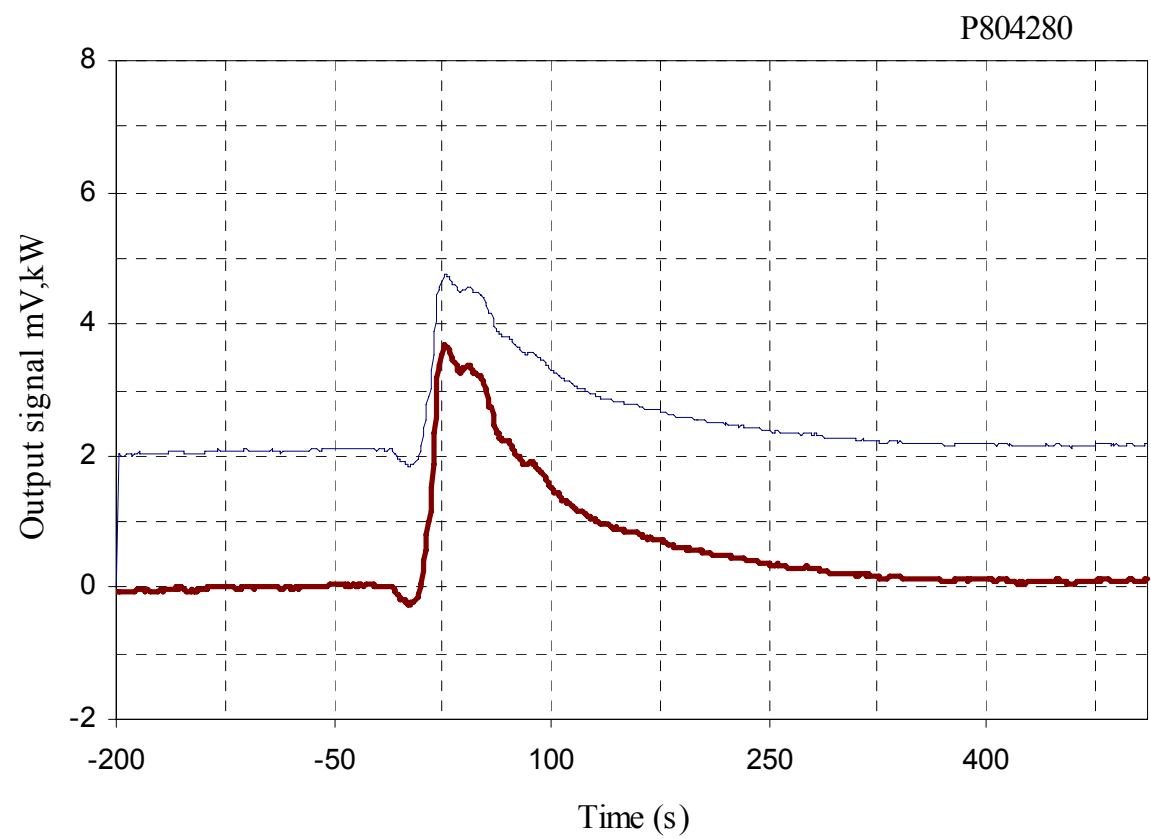

Figure $2 \quad$ Heat release rate for test no 2.

Total heat release: 0.4 MJ. Peak heat release rate: $3.7 \mathrm{~kW}$. 


\section{C.5.4 Conditioning}

Temperature $23 \pm 2{ }^{\circ} \mathrm{C}$.

Relative humidity $(50 \pm 5) \%$.

\section{C.5.5 Date of test}

September 8 and 29, 2009. 


\section{C.6 Product No. 6}

Blue (front) and green/black (back) fabric consisting of $55 \%$ polyester and $45 \%$ wool. The product has an area weight of $829 \mathrm{~g} / \mathrm{m}^{2}$.

\section{C.6.1 Observations made during fire test}

\begin{tabular}{|l|c|c|}
\hline Test no & 1 & 2 \\
\hline $\begin{array}{l}\text { Flames at flame } \\
\text { front went out }\end{array}$ & $11: 35$ at $610 \mathrm{~mm}$ & $11: 15$ at $600 \mathrm{~mm}$ \\
\hline Burning droplets & none & none \\
\hline
\end{tabular}

\section{C.6.2 Derived fire characteristics}

\begin{tabular}{|l|c|c|c|c|c|}
\hline Test no & 1 & 2 & & Average & $\begin{array}{l}\text { Surface } \\
\text { flammability } \\
\text { criteria }\end{array}$ \\
\hline Heat for ignition, $\mathrm{MJ} / \mathrm{m}^{2}$ & 0.6 & 0.5 & & $\underline{0.6}$ & - \\
\hline $\begin{array}{l}\text { Avera ge heat for sustained } \\
\text { burning, } \mathrm{Q}_{\mathrm{sb}}, \mathrm{MJ} / \mathrm{m}^{2}\end{array}$ & 1 & 1 & & $\underline{1}$ & $\geq 1.5$ \\
\hline $\begin{array}{l}\text { Critical flux at extinguishement, } \\
\text { CFE, } \mathrm{kW} / \mathrm{m}^{2}\end{array}$ & 4.2 & 4.5 & & $\underline{4.3}$ & $\geq 20.0$ \\
\hline Total heat release, $\mathrm{Q}_{\mathrm{t}}, \mathrm{MJ}$ & 0.8 & 0.5 & & $\underline{0.6}$ & $\leq 0.7$ \\
\hline Peak heat release rate, $\mathrm{Q}_{\mathrm{p}}, \mathrm{kW}$ & 8.5 & 5.4 & & $\underline{7}$ & $\leq 4.0$ \\
\hline
\end{tabular}




\section{C.6.3 Heat release rates, graphs}

Test 1

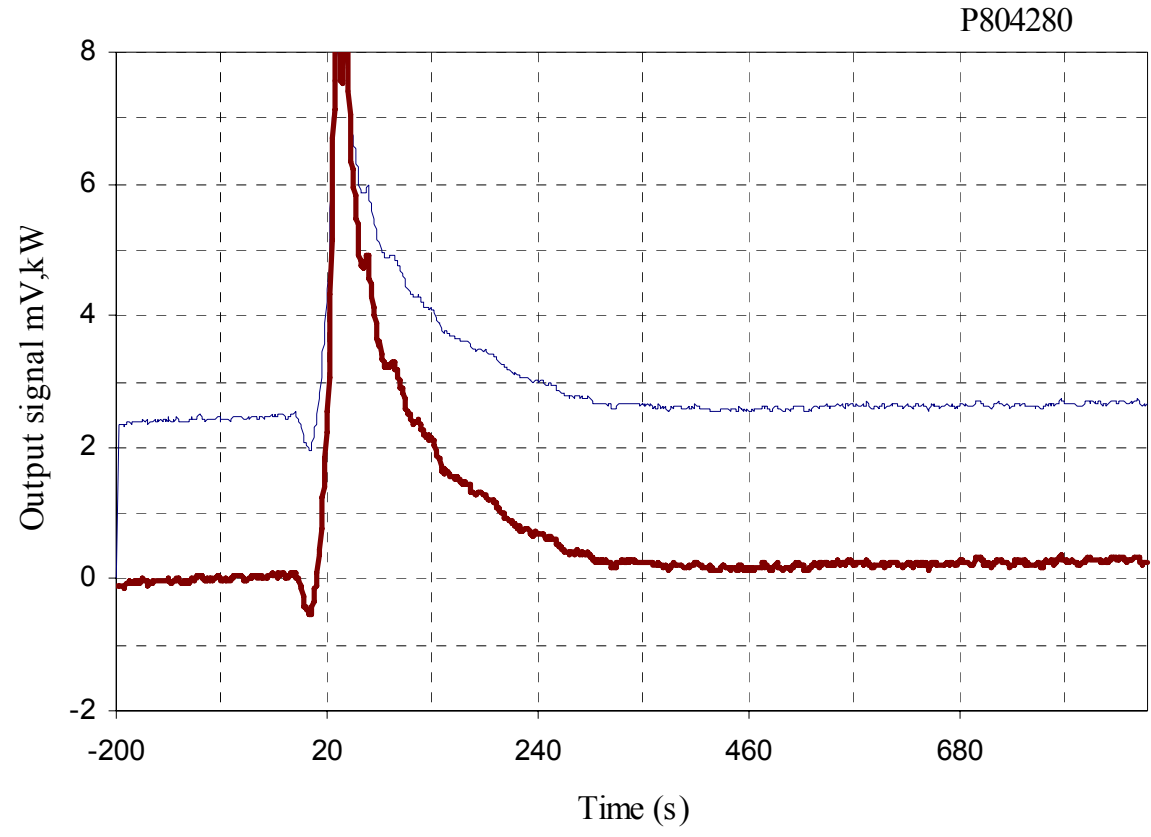

Figure $1 \quad$ Heat release rate for test no 1 .

Total heat release: 0.8 MJ. Peak heat release rate: $8.5 \mathrm{~kW}$.

Test 2

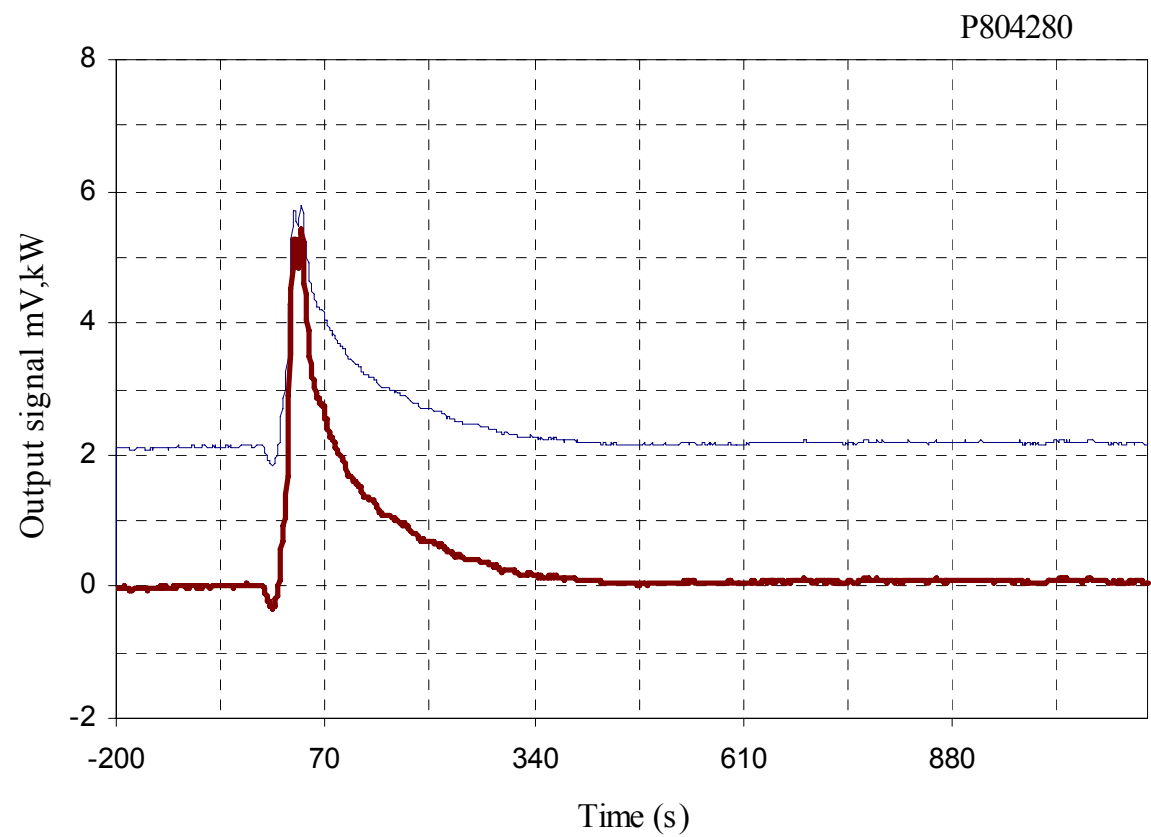

Figure $2 \quad$ Heat release rate for test no 2.

Total heat release: $0.5 \mathrm{MJ}$. Peak heat release rate: $5.4 \mathrm{~kW}$. 


\section{C.6.4 Conditioning}

Temperature $23 \pm 2{ }^{\circ} \mathrm{C}$.

Relative humidity $(50 \pm 5) \%$.

\section{C.6.5 Date of test}

September 8 and 29, 2009. 


\section{C.7 Product No. 7}

Dark blue (front) and dark grey (back) fabric consisting of wool velvet blend. The product has an area weight of $974 \mathrm{~g} / \mathrm{m}^{2}$.

\section{C.7.1 Observations made during fire test}

Om max flamfront ej överstiger $180 \mathrm{~mm}$ skall inte Qsb presenteras.

\begin{tabular}{|l|c|c|}
\hline Test no & 1 & 2 \\
\hline $\begin{array}{l}\text { Flames at flame } \\
\text { front went out }\end{array}$ & $01: 20$ at $340 \mathrm{~mm}$ & $02: 08$ at $430 \mathrm{~mm}$ \\
\hline Burning droplets & none & none \\
\hline
\end{tabular}

\section{C.7.2 Derived fire characteristics}

\begin{tabular}{|l|c|c|c|c|c|}
\hline Test no & 1 & 2 & & Average & $\begin{array}{l}\text { Surface } \\
\text { flammability } \\
\text { criteria }\end{array}$ \\
\hline Heat for ignition, MJ/m ${ }^{2}$ & 0.3 & 0.2 & & $\underline{0.3}$ & - \\
\hline $\begin{array}{l}\text { Avera ge heat for sustained } \\
\text { burning, } \mathrm{Q}_{\mathrm{sb}}, \mathrm{MJ} / \mathrm{m}^{2}\end{array}$ & 0.4 & 0.5 & & $\underline{0.4}$ & $\geq 1.5$ \\
\hline $\begin{array}{l}\text { Critical flux at extinguishement, } \\
\mathrm{CFE}, \mathrm{kW} / \mathrm{m}^{2}\end{array}$ & 25.1 & 15.8 & & $\underline{20.4}$ & $\geq 20.0$ \\
\hline Total heat release, $\mathrm{Q}_{\mathrm{t}}, \mathrm{MJ}$ & 0.6 & 0.5 & & $\underline{0.5}$ & $\leq 0.7$ \\
\hline Peak heat release rate, $\mathrm{Q}_{\mathrm{p}}, \mathrm{kW}$ & 8.9 & 6 & & $\underline{7.4}$ & $\leq 4.0$ \\
\hline
\end{tabular}




\section{C.7.3 Heat release rates, graphs}

Test 1

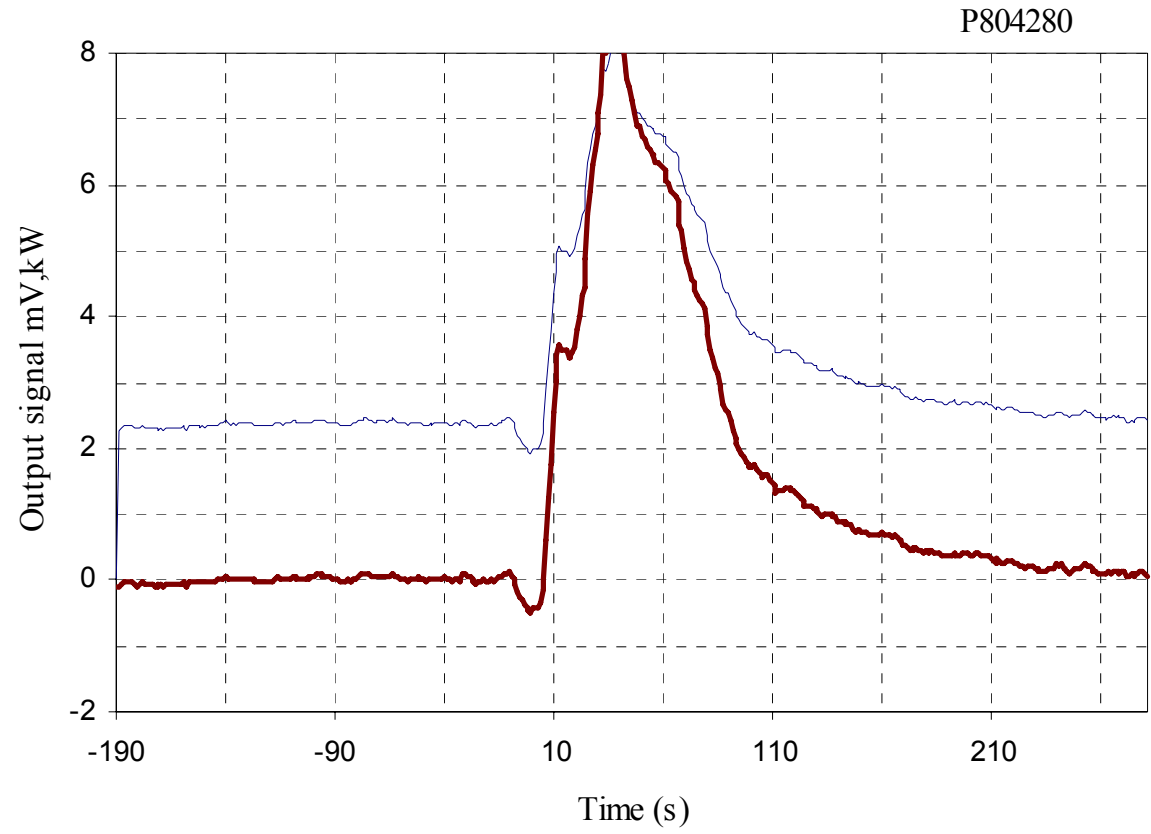

Figure 1 Heat release rate for test no 1.

Total heat release: 0.6 MJ. Peak heat release rate: $8.9 \mathrm{~kW}$.

Test 2

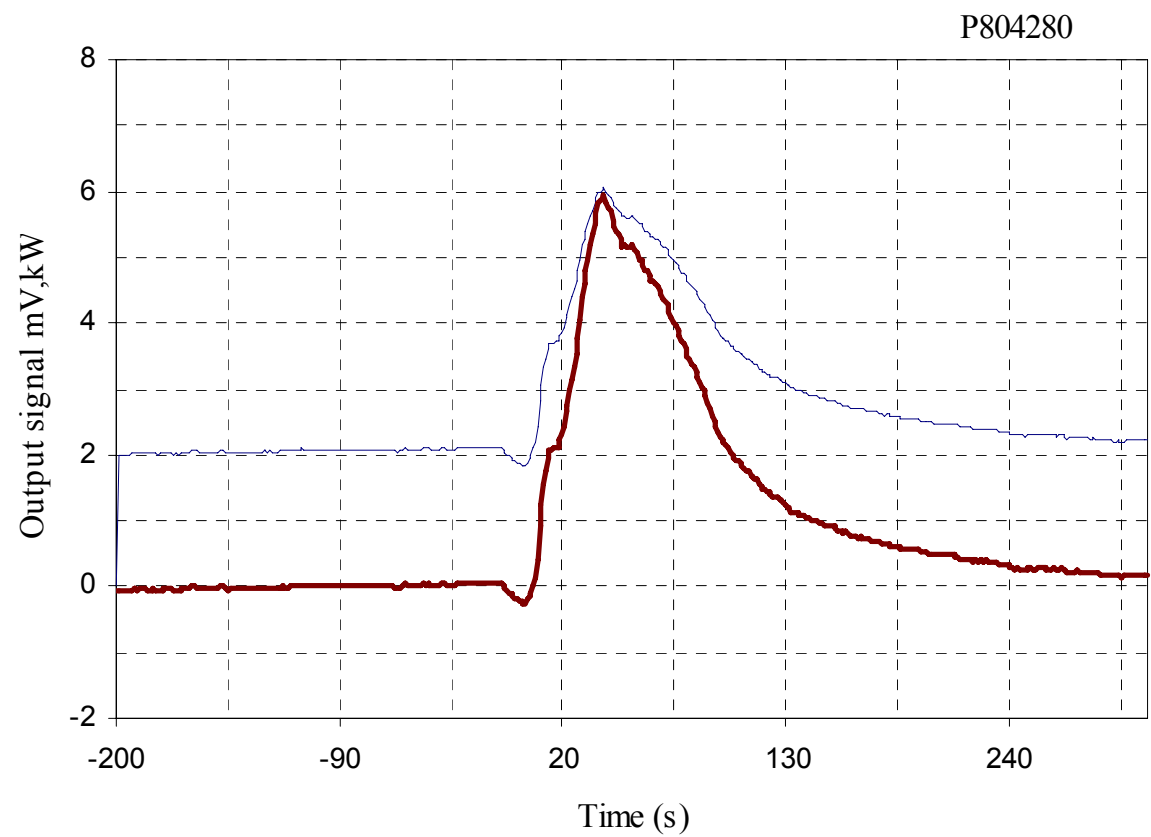

Figure 2 Heat release rate for test no 2.

Total heat release: $0.5 \mathrm{MJ}$. Peak heat release rate: $6.0 \mathrm{~kW}$.

Test 3 


\section{C.7.4 Conditioning}

Temperature $23 \pm 2{ }^{\circ} \mathrm{C}$.

Relative humidity $(50 \pm 5) \%$.

\section{C.7.5 Date of test}

September 8 and 29, 2009. 


\section{C.8 Product No. 8}

Dark blue (front) and multicoloured (back) fabric consisting of $85 \%$ wool and $15 \%$ nylon. The product has an area weight of $856 \mathrm{~g} / \mathrm{m}^{2}$.

\section{C.8.1 Observations made during fire test}

\begin{tabular}{|l|c|c|}
\hline Test no & 1 & 2 \\
\hline $\begin{array}{l}\text { Flames at flame } \\
\text { front went out }\end{array}$ & $01: 20$ at $290 \mathrm{~mm}$ & $01: 20$ at $350 \mathrm{~mm}$ \\
\hline Burning droplets & none & none \\
\hline
\end{tabular}

\section{C.8.2 Derived fire characteristics}

\begin{tabular}{|l|c|c|c|c|c|}
\hline Test no & 1 & 2 & & Average & $\begin{array}{l}\text { Surface } \\
\text { flammability } \\
\text { criteria }\end{array}$ \\
\hline Heat for ignition, $\mathrm{MJ} / \mathrm{m}^{2}$ & 0.3 & 0.2 & & $\underline{0.3}$ & - \\
\hline $\begin{array}{l}\text { Avera ge heat for sustained } \\
\text { burning, } \mathrm{Q}_{\mathrm{sb}}, \mathrm{MJ} / \mathrm{m}^{2}\end{array}$ & 0.4 & 0.3 & & $\underline{0.3}$ & $\geq 1.5$ \\
\hline $\begin{array}{l}\text { Critical flux at extinguishement, } \\
\text { CFE, } \mathrm{kW} / \mathrm{m}^{2}\end{array}$ & 31.5 & 24 & & $\underline{27.8}$ & $\geq 20.0$ \\
\hline Total heat release, $\mathrm{Q}_{\mathrm{t}}, \mathrm{MJ}$ & 0.4 & 0.3 & & $\underline{0.4}$ & $\leq 0.7$ \\
\hline Peak heat release rate, $\mathrm{Q}_{\mathrm{p}}, \mathrm{kW}$ & 8 & 5.3 & & $\underline{6.6}$ & $\leq 4.0$ \\
\hline
\end{tabular}




\section{C.8.3 Heat release rates, graphs}

Test 1

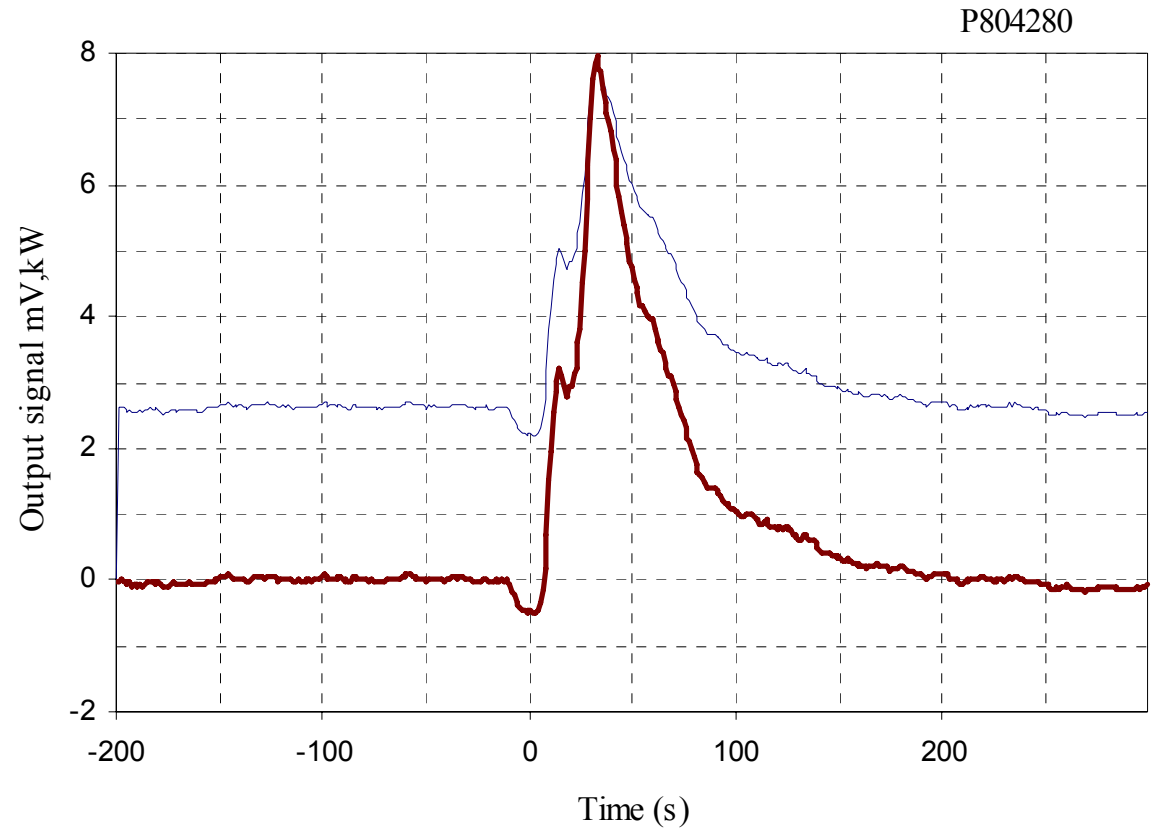

Figure $1 \quad$ Heat release rate for test no 1.

Total heat release: 0.4 MJ. Peak heat release rate: $8.0 \mathrm{~kW}$.

Test 2

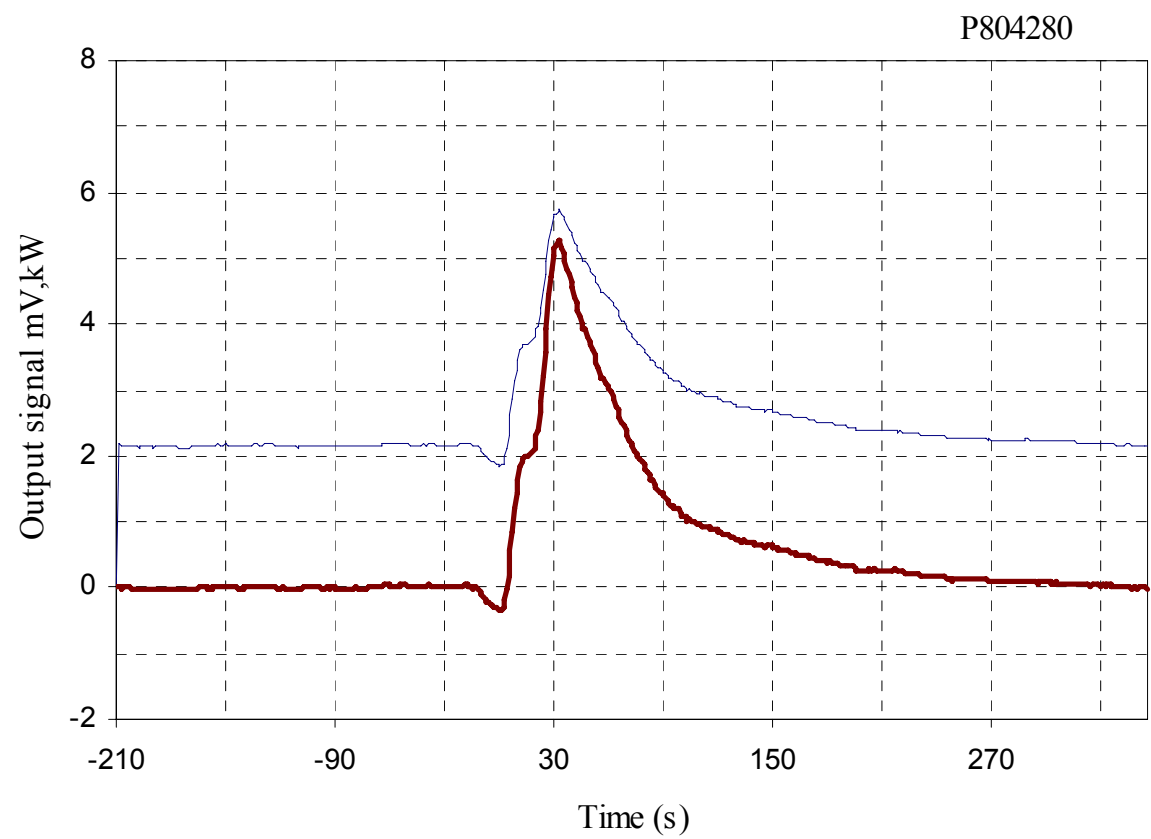

Figure 2 Heat release rate for test no 2.

Total heat release: $0.3 \mathrm{MJ}$. Peak heat release rate: $5.3 \mathrm{~kW}$. 


\section{C.8.4 Conditioning}

Temperature $23 \pm 2{ }^{\circ} \mathrm{C}$.

Relative humidity $(50 \pm 5) \%$.

\section{C.8.5 Date of test}

September 8 and 29, 2009. 
C.9 Product No. 9

No tests performed. 


\section{C.10 Product No. 10}

Dark blue (front) and multicoloured (back) fabric consisting of $56 \%$ wool, $35 \%$ cotton and $9 \%$ nylon. The product has an area weight of $826 \mathrm{~g} / \mathrm{m}^{2}$.

\section{C.10.1 Observations made during fire test}

\begin{tabular}{|l|c|}
\hline Test no & 1 \\
\hline $\begin{array}{l}\text { Flames at flame } \\
\text { front went out }\end{array}$ & $01: 24$ at $380 \mathrm{~mm}$ \\
& \\
\hline Burning droplets & none \\
\hline
\end{tabular}

\section{C.10.2 Derived fire characteristics}

\begin{tabular}{|l|c|c|c|c|c|}
\hline Test no & 1 & & & Average & $\begin{array}{l}\text { Surface } \\
\text { flammability } \\
\text { criteria }\end{array}$ \\
\hline Heat for ignition, $\mathrm{MJ} / \mathrm{m}^{2}$ & 0.2 & & & $\underline{0.2}$ & - \\
\hline $\begin{array}{l}\text { Avera ge heat for sustained } \\
\text { burning, } \mathrm{Q}_{\mathrm{sb}}, \mathrm{MJ} / \mathrm{m}^{2}\end{array}$ & 0.4 & & & $\underline{0.4}$ & $\geq 1.5$ \\
\hline $\begin{array}{l}\text { Critical flux at extinguishement, } \\
\text { CFE, } \mathrm{kW} / \mathrm{m}^{2}\end{array}$ & 20.5 & & & $\underline{20.5}$ & $\geq 20.0$ \\
\hline Total heat release, $\mathrm{Q}_{\mathrm{t}}, \mathrm{MJ}$ & 0.5 & & & $\underline{0.5}$ & $\leq 0.7$ \\
\hline Peak heat release rate, $\mathrm{Q}_{\mathrm{p}}, \mathrm{kW}$ & 8.7 & & & $\underline{8.7}$ & $\leq 4.0$ \\
\hline
\end{tabular}




\section{C.10.3 Heat release rates, graphs}

Test 1

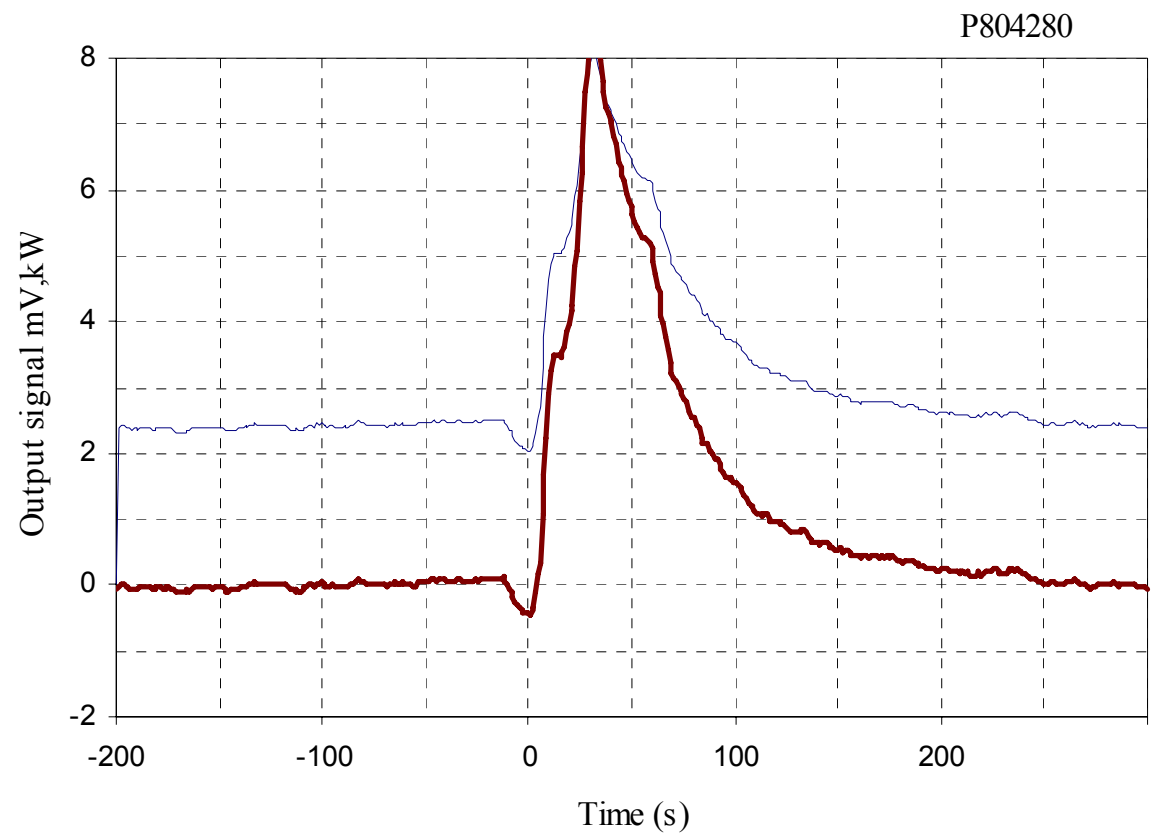

Figure $1 \quad$ Heat release rate for test no 1.

Total heat release: 0.5 MJ. Peak heat release rate: $8.7 \mathrm{~kW}$.

\section{C.10.4 Conditioning}

Temperature $23 \pm 2{ }^{\circ} \mathrm{C}$.

Relative humidity $(50 \pm 5) \%$.

\section{C.10.5 Date of test}

September 8, 2009. 


\section{C.11 Product No. 11}

Grey needle felt fabric consisting of $100 \%$ polypropylene fibre. The product has an area weight of $510 \mathrm{~g} / \mathrm{m}^{2}$.

\section{C.11.1 Observations made during fire test}

\begin{tabular}{|l|c|c|}
\hline Test no & 1 & 2 \\
\hline $\begin{array}{l}\text { Flames at flame } \\
\text { front went out }\end{array}$ & $07: 36$ at $450 \mathrm{~mm}$ & $09: 33$ at $490 \mathrm{~mm}$ \\
\hline Burning droplets & none & none \\
\hline
\end{tabular}

\section{C.11.2 Derived fire characteristics}

\begin{tabular}{|l|c|c|c|c|c|}
\hline Test no & 1 & 2 & & Average & $\begin{array}{l}\text { Surface } \\
\text { flammability } \\
\text { criteria }\end{array}$ \\
\hline Heat for ignition, $\mathrm{MJ} / \mathrm{m}^{2}$ & 0.5 & 1.6 & & $\underline{1}$ & - \\
\hline $\begin{array}{l}\text { Avera ge heat for sustained } \\
\text { burning, } \mathrm{Q}_{\mathrm{sb}}, \mathrm{MJ} / \mathrm{m}^{2}\end{array}$ & 4.4 & 2.4 & & $\underline{3.4}$ & $\geq 1.5$ \\
\hline $\begin{array}{l}\text { Critical flux at extinguishement, } \\
\text { CFE, } \mathrm{kW} / \mathrm{m}^{2}\end{array}$ & 13.5 & 10.5 & & $\underline{12}$ & $\geq 20.0$ \\
\hline Total heat release, $\mathrm{Q}_{\mathrm{t}}, \mathrm{MJ}$ & 0.5 & 0.2 & & $\underline{0.3}$ & $\leq 0.7$ \\
\hline Peak heat release rate, $\mathrm{Q}_{\mathrm{p}}, \mathrm{kW}$ & 1.9 & 1.4 & & $\underline{1.6}$ & $\leq 4.0$ \\
\hline
\end{tabular}




\section{C.11.3 Heat release rates, graphs}

Test 1

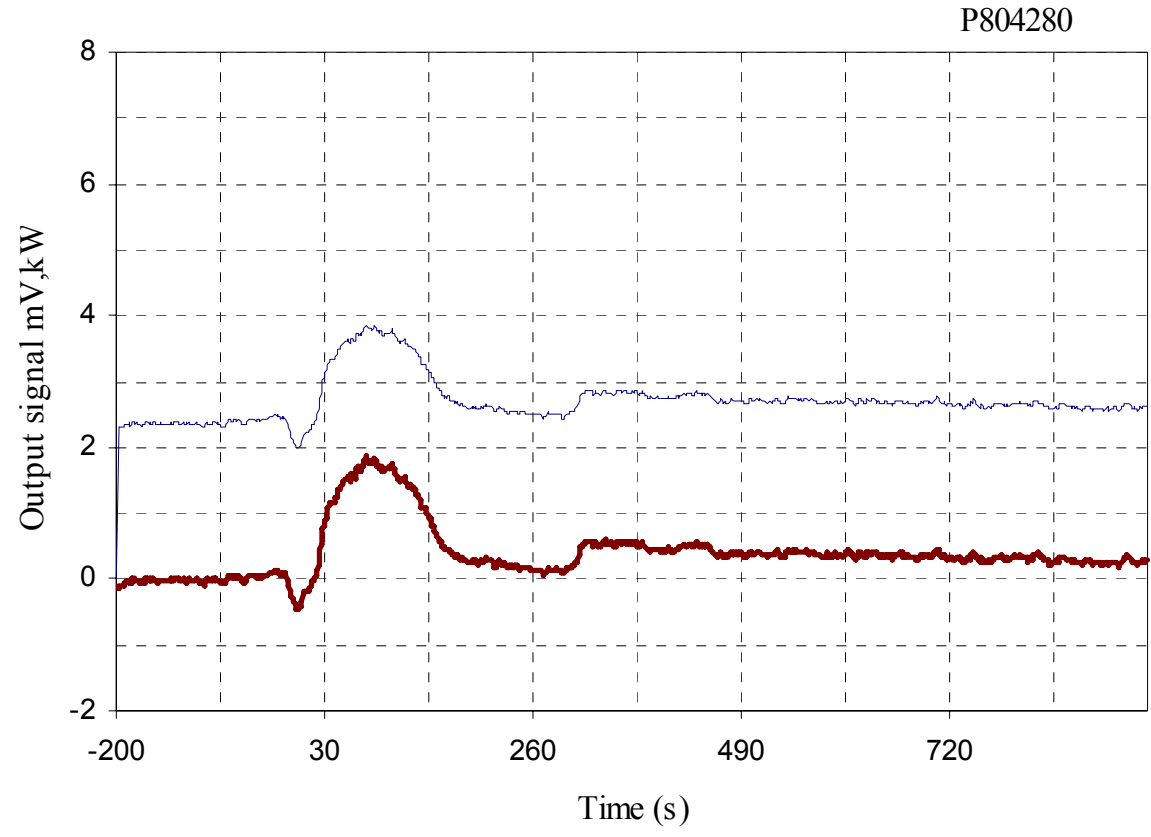

Figure $1 \quad$ Heat release rate for test no 1 .

Total heat release: 0.5 MJ. Peak heat release rate: $1.9 \mathrm{~kW}$.

Test 2

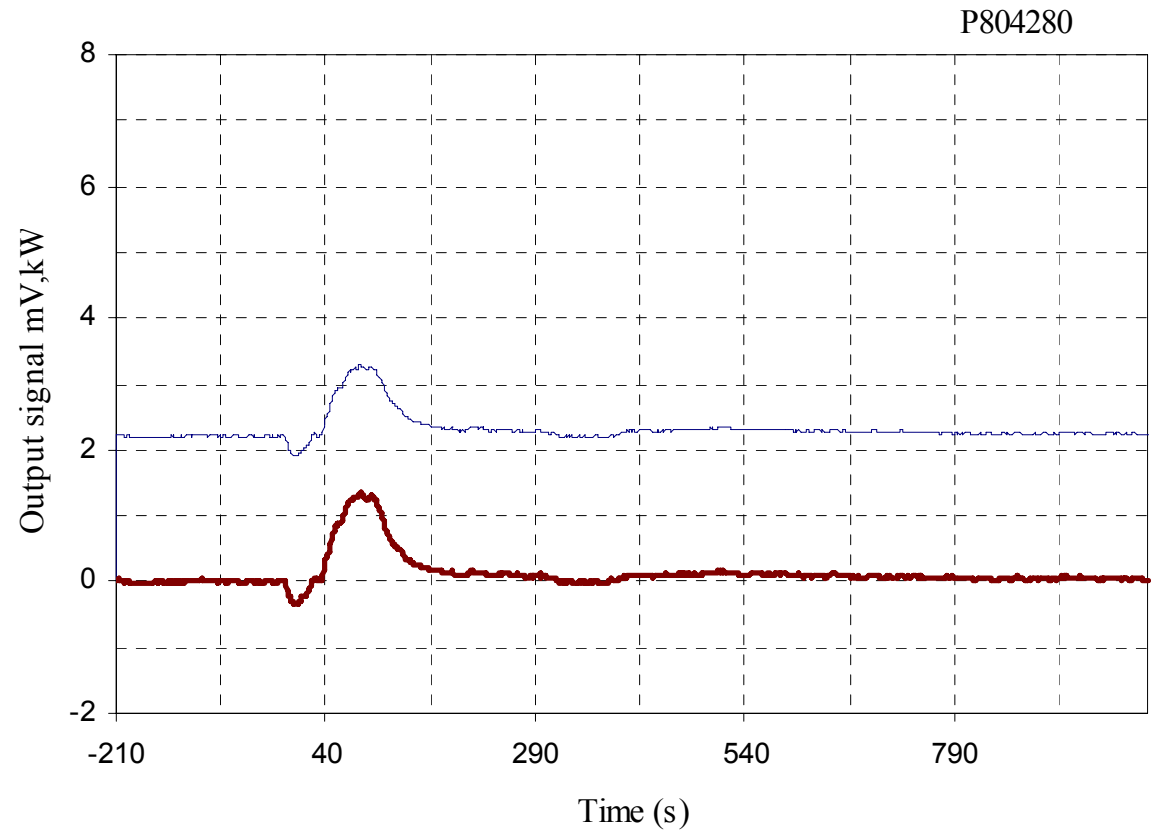

Figure $2 \quad$ Heat release rate for test no 2.

Total heat release: $0.2 \mathrm{MJ}$. Peak heat release rate: $1.4 \mathrm{~kW}$. 


\section{C.11.4 Conditioning}

Temperature $23 \pm 2{ }^{\circ} \mathrm{C}$.

Relative humidity $(50 \pm 5) \%$.

\section{C.11.5 Date of test}

September 8 and 30, 2009. 


\section{References}

1. ISO 3795, Road vehicles, and tractors and machinery for agriculture and forestry - Determination of burning behaviour of interior materials, International Organization for Standardization, Geneva, 1989.

2. Directive 95/28/EC of the European Parliament and of the Council of 24 October 1995 relating to the burning behaviour of materials used in the interior construction of certain categories of motor vehicle, EU, 1995.

3. UNECE Regulation No. 118: Uniform technical prescription concerning the burning behaviour of materials used in the interior construction of certain categories of motor vehicles., UNECE, 2005.

4. FMVSS 302, Flammability of Interior Materials, U.S.Department of Transportation, 1991.

5. Digges KH, Gann RG, Grayson SJ, Hirschler MM, Lyon RE, Purser DA, Quintiere JG, Stephenson RR, Tewarson A, Improving survivability in motor vehicle fires, Fire and Materials, San Francisco, 2007.

6. Johansson P, Axelsson J, WP2 report: Fire safety review of interior materials in buses. SP Sveriges Tekniska Forskningsinstitut, SP Report 2006:59, 2006.

7. Försth M, Hagerupsen A, Petzäll J, Informal document No. GRSG-95-30: Ensuring fire safety in buses, Working Party on General Safety Provisions, GRSG, UNECE, Geneva, 2008.

8. ISO 6941, Textile fabrics - Burning behaviour - Measurement of flame spread properties of vertically oriented specimens, International Organization for Standardization, Geneve, 2003.

9. Informal document No. GRSG-96-05: Proposal for draft amendments to Regulation No. 118, Working Party on General Safety Provisions, GRSG, UNECE, Geneva, 2009.

10. ISO 5658-2: Reaction to fire tests - Spread of flame - Part 2: Lateral spread on building and transport products in vertical configuration, 2006.

11. Informal document No. GRSG-95-19: Justification and proposed draft amendments to Regulation No. 118, improvement of bus fire safety, Working Party on General Safety Provisions, GRSG, UNECE, Geneva, 2008.

12. IMO Resolution A.653(16), Recommendation on improved fire test procedures for surface flammability of bulkhead, ceiling and deck finish materials, International Maritime Organization, 1989.

13. CEN/TS 45545-2: Railway applications - Fire protection on railway vehicles Part 2: Requirements for fire behaviour of materials and components, Comité Européen de Normalisation, 2009.

14. (2009) GRSG-96-27 Proposal for draft amendment to Regulation No 118. GRSG-96, http://www.unece.org/trans/doc/2009/wp29grsg/GRSG-96-27e.pdf 
SP Technical Research Institute of Sweden develops and transfers technology for improving competitiveness and quality in industry, and for safety, conservation of resources and good environment in society as a whole. With Sweden's widest and most sophisticated range of equipment and expertise for technical investigation, measurement, testing and certification, we perform research and development in close liaison with universities, institutes of technology and international partners.

SP is a EU-notified body and accredited test laboratory. Our headquarters are in Borås, in the west part of Sweden.

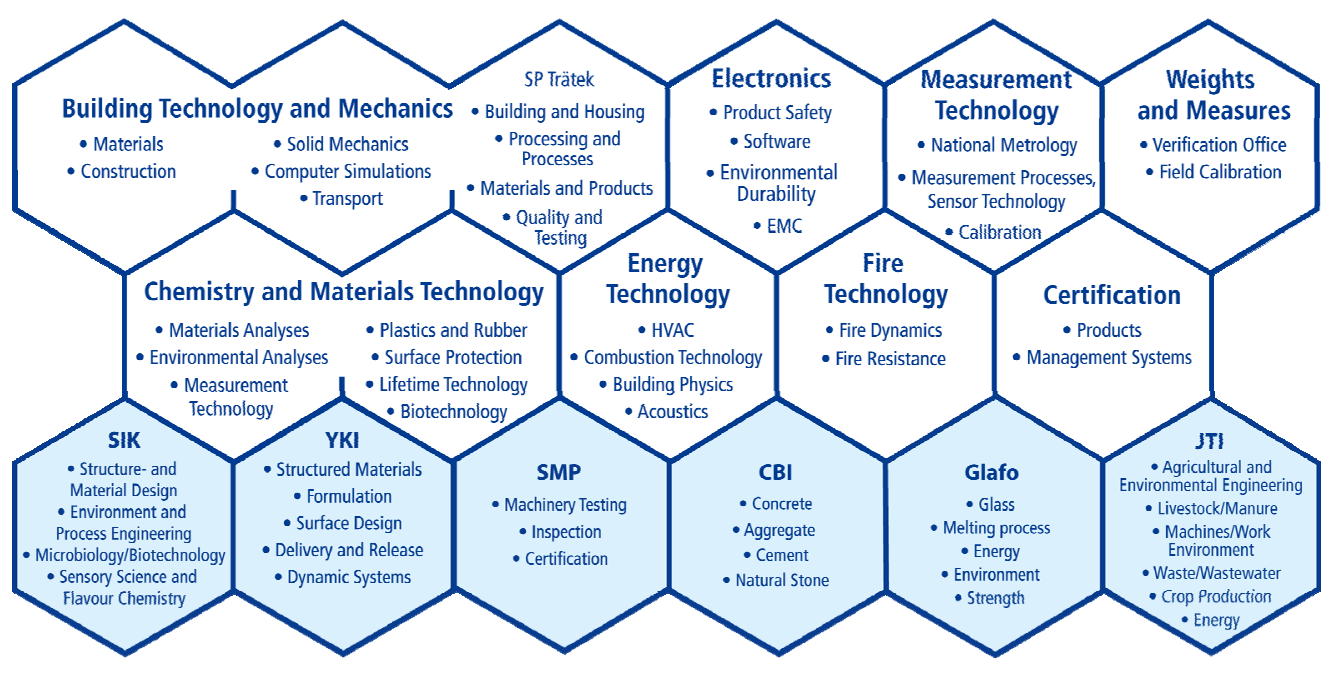

SP consists of eight technology units and six subsidiary companies. Three of the companies CBI, Glafo and JTI are each $60 \%$ owned by SP and $40 \%$ by their respective industries.

\section{SP Technical Research Institute of Sweden}

Box 857, SE-501 15 BORÅS, SWEDEN

Telephone: +461051650 00, Telefax: +4633135502

E-mail: info@sp.se, Internet: www.sp.se

www.sp.se
Fire Technology

SP Arbetsrapport 2009:23

ISSN 0284-5172 